\title{
Sedir (Cedrus libani A. Rich.) ağaçlandırma alanlarında karbon stoklarının belirlenmesi
}

\author{
Rıza KARATAŞ (Orcid: 0000-0002-0940-3944) ${ }^{1 *}$, Aydın ÇÖMEZ (Orcid: 0000-0002-1972-0396)', \\ Şükrü Teoman GÜNER (Orcid: 0000-0002-3058-7899) ${ }^{1}$
}

${ }^{1}$ Orman Toprak ve Ekoloji Araştırmaları Enstitüsü Müdürlüğü, ESKİŞEHİR

*Sorumlu yazar/Corresponding author: rizakaratas@ogm.gov.tr, Geliş Tarihi/Recived: 13.09.2017, Kabul Tarihi/Accepted: 26.10.2017

$\ddot{\mathbf{O z}}$

Bu çalışma, sedir (Cedrus libani A. Rich.) ağaçlandırma alanlarındaki karbon stoklarını belirlemek amacıyla yapılmıştır. Örneklemeler, Eskişehir ve Afyonkarahisar illerinde verim sınıfı, gelişim çağı ve kapalılık bakımından farklılık gösteren 40 alanda yapılmıştır. Her örnek alandaki ağaçların çap ve boyları ölçülmüş, bir ağaç kesilmiş ve kesilen ağacın kökü çıkartılmıştır. Daha sonra arazide ibre, kuru dal, canlı dal, gövde ve kök taze ağırlıkları tartılmıştır. Örnek alanlarda çalı, ot ve ölü örtü örneklemesi yapılmış ve her bileşene ait alt örnekler alınmıştır. Ayrıca her örnek alanda bir adet toprak çukuru açılarak ayrılan horizonlardan toprak örnekleri alınmıştır. Laboratuvarda bitki ve toprak örneklerinin bazı fiziksel ve kimyasal özellikleri belirlenmiştir. Tek ağaç kütle denklemlerinin geliştirilmesinde regresyon analizlerinden yararlanılmıştır. Elde edilen verilerden örnek alanların hektardaki ağaç bileşenleri, diri örtü, ölü örtü ve toprak karbon stokları hesaplanmıştır. Örnek alanlardaki bitkisel kütle miktarı, bitkisel kütlenin karbon oranları ve karbon stokları ile toprak horizonlarının karbon oranları ve toprak karbon stoklarının meşcere tiplerine göre değişimi varyans analizi ile değerlendirilmiştir. Sedir ağaçlandırmaları için hacim ağırlığ $0,467 \mathrm{t} / \mathrm{m}^{3}$, BGK $_{\text {TOPRAKÜstü }} 1,635$, BDGK $_{\text {TOPRAкÜstü }} 0,762 \mathrm{t} / \mathrm{m}^{3}$, kök/sak oran1 0,207 ve karbon oran1 \%51,27 bulunmuştur. Ortalama karbon stoğu ağaçlarda $61,084 \mathrm{tC} /$ ha, çalılarda 1,060 tC/ha, otlarda $0,625 \mathrm{tC} /$ ha, ölü örtüde 6,55 tC/ha ve toprakta 60,875 tC/ha olarak belirlenmiştir. Ağaç kütlesi, toprak, ölü örtü ve toplam karbon stoğu meşcere tipleri arasında önemli farklılıklar göstermiştir. Ancak, ot ve çalı karbon stoğunun meşcere tiplerine göre farklılıkları önemli düzeyde değildir.

Anahtar Kelimeler: Sedir, ağaçlandırma, bitkisel kütle, karbon stokları

\section{Determination of carbon stocks in cedar (Cedrus libani A. Rich.) afforestation areas}

\begin{abstract}
This research was carried out to determine the carbon stocks of Taurus cedar (Cedrus libani A. Rich.) plantation areas. 40 sample plots were chosen from areas differing in terms of yield classes, growth stages and canopy closure, in Eskişehir and Afyonkarahisar cities. In each sample plot tree height and diameter at breast height (DBH) of all trees were measured and a sample tree was cut and roots were excavated. Fresh weight of the tree compartments including needle, dead and live branches, bole and root was determined after cutting. Shrub, herbaceous cover and forest floor samplings were made and subsamples were collected from each sample plot. A soil pit was dug and soil core samples were taken from the identified horizons for every sample plots. Some physical and chemical properties of soil and plant specimen were analyzed in the laboratory. Stem volume and biomass equations were developed by regression analysis. Carbon stocks of tree biomass components, shrub and herbaceous cover, forest floor and soil were estimated from the data obtained from the measurements. Changes in biomass, carbon factors, and carbon stocks of biomass, forest floor and soil according to stand types were evaluated by Anova. As a result, basic wood density was calculated as $0.467 \mathrm{t} / \mathrm{m}^{3}$ while $\mathrm{BEF}_{\mathrm{ABOVEGROUND}}$ as $1.635, \mathrm{BCEF}_{\mathrm{ABOVEGRound}}$ as $0.762 \mathrm{t} / \mathrm{m}^{3}$, root to shoot ratio as 0.207 and carbon factor as 51.27 percent. Mean carbon stock of tree biomass was found as $61.084 \mathrm{t} / \mathrm{ha}$ while $1.060 \mathrm{t} / \mathrm{ha}, 0.625 \mathrm{t} / \mathrm{ha}, 6.55$ $\mathrm{t} / \mathrm{ha}$, and $60.875 \mathrm{t} / \mathrm{ha}$ for shrub, herbaceous cover, forest floor and soil, respectively. Tree biomass, soil carbon stocks of stand types and total carbon stocks were found different between the stand types. But the differences were not significant in shrub, herbaceous cover and forest floor.
\end{abstract}

Key words: Cedrus libani, afforestation, biomass, carbon stocks

To cite this article (Atıf): Karataş, R, Çömez, A , Güner, Ş . (2017). Sedir (Cedrus libani A. Rich.) ağaçlandırma alanlarında karbon stoklarının belirlenmesi. Ormancılık Araștırma Dergisi, 4 (2), 107-120.

DOI: http://dx.doi.org/10.17568/ogmoad.338029 


\section{Giriş}

İklim değişimine sebep olan başlıca etkenin sera gazlarının atmosferdeki konsantrasyonlarının artması olduğu bildirilmektedir (Nowak ve Crane 2002, Schimel ve ark. 2000). Sera gazları içerisinde en önemli pay karbondioksite aittir. Orman ekosistemleri bitkisel kütle ve toprakta depoladığ 1 karbon miktarı ile atmosfere salımları azaltabilecek ve aynı zamanda insanlar tarafından değiştirilebilen en önemli yutakları oluşturmaktadır (Çömez 2012).

Küresel iklim değişimi sorununun çözümü için Birleşmiş Milletler tarafından 1992 yılında Rio'da yapılan zirvede "Birleşmiş Milletler İklim Değişikliği Çerçeve Sözleşmesi (UNFCCC)" imzaya açılmış ve bu sözleşmenin uygulanması amacıyla 1997 yılında Kyoto Protokolü oluşturulmuştur. Kyoto Protokolü yükümlülükleri kapsamında ülkeler, her yıl enerji, ulaşım, atık, tarım ve arazi kullanımı-arazi kullanım değişikliği ve ormancılık sektörlerinden kaynaklanan sera gazı salımlarını ve atmosferden alınarak bağlanan karbon miktarlarına ait ulusal envanter raporlarını (NIR) hazırlayarak UNFCCC sekretaryasına sunmaktadırlar.

Türkiye, 2006 yılından itibaren ulusal bildirimlerini yapmaktadır. Bu bildirimler "Arazi Kullanımı, Arazi Kullanım Değişikliği ve Ormancılık” (AKAKDO) kılavuzuna göre ve kılavuzda verilen katsayılar kullanılarak düzenlenmiştir. AKAKDO kılavuzundaki katsayıların bir kısmı Türkiye'de çeşitli ağaç türleri için yapılan çalışmaların sonuçlarına göre hesaplanmış olup, diğer bazı katsayılar ise dünya ölçeğinde genel katsayılardır. Söz konusu genel katsayıların Türkiye için çok sağlıklı sonuçlar vereceğini söylemek mümkün değildir. Orman ekosistemleri için ülkemizde yapılmış araştırma sayısı azdır. Bundan sonra yapılacak bildirimlerde veri kalitemizi yükseltmek için Türkiye'ye özgü araştırmaların yapılması gerekmektedir.

Ormancılık sektöründe karbon envanteri, kabuklu gövde hacmi verilerinden yararlanılarak yapılmaktadır. Kabuklu gövde hacmi önce hacim ağırlığı kullanılarak gövde kütlesine dönüştürülmekte, daha sonra bitkisel kütle genişletme katsayıları ile çarpılarak ağaçların toprak üstü kısımlarının kütlesi hesaplanmaktadır. Kök kütlesi, toprak üstü kütle ile kök/sak oranının çarpımı sonucu bulunmaktadır. Ya da Tarım, Ormancılık ve Arazi Kullanımı (AFOLU) kılavuzuna göre (IPCC 2006), kabuklu gövde hacmi doğrudan bitkisel kütle dönüştürme ve genişletme katsayıları ile çarpılarak toprak üstü ağaç kütlesi hesaplanmaktadır. Ancak ağaçlandırmalar için geliştirilmiş katsayılar ülkemizde henüz mevcut değildir. Bu çalışma, ihtiyaç duyulan katsayıların üretilmesi bakımından önemlidir.
Sera gazı envanterlerinde arazi kullanım değişikliğinden kaynaklanan karbon salım ve bağlanma miktarları önemli bir yer tutmaktadır. Bu araştırma, daha önce orman olmayan arazilerin ağaçlandırılması ile oluşturulan arazi kullanım değişikliğinin karbon bağlanmasına etkisinin ortaya konulması bakımından da önemlidir.

Türkiye'de doğal sedir ormanlarının toprak üstü bitkisel kütlesi ve karbon stoğu üzerine yapılmış bir çalışma bulunmaktadır (Durkaya ve ark. 2013). Ancak dikim yoluyla yetiştirilmiş sedir meşcereleri için bitkisel kütle denklemleri mevcut değildir. Ayrıca sedirin toprak altı bitkisel kütlesi konusunda da araştırmalara ihtiyaç bulunmaktadır. Türkiye'de doğal ve ağaçlandırma ile tesis edilmiş sedir meşcerelerindeki toprak özellikleri ve karbon stoklarına ilişkin araştırmalar mevcuttur (Özkan 2000, Polat ve ark. 2014, Akgül ve Y1lmaz 1986, Sürücü 2012, Karataş ve Özkan 2017). Ancak sedir meşcerelerindeki ölü örtü, diri örtü ve ağaç bileşenlerine ait özellikler ile karbon stoklarına ilişkin verilere ihtiyaç bulunmaktadır. Bu çalışma, ekosistemin bütün bileşenlerini içermesi bakımından diğer çalışmalardan ayrilmaktadır.

Çalışmanın amacı, sedir ağaçlandırma alanlarında, çeşitli meşcere tiplerinin, toprak üstü ve toprak altı bitkisel kütlesi ile diri örtü, ölü örtü ve toprakta depolanan karbon miktarını ortaya koymaktır. Elde edilen kütle denklemleri, bitkisel kütle katsayıları, karbon oranları ve karbon stokları amenajman planlarının yapımında ve ulusal sera gazı envanterinde kullanılabilir.

\section{Materyal ve Yöntem}

\subsection{Araştırma Alanının Tanıtımı}

Araştırma alanı $37^{\circ} 46^{\prime}-40^{\circ} 10^{\prime}$ kuzey enlemleri ile $29^{\circ} 40^{\prime}-32^{\circ} 01^{\prime}$ doğu boylamları arasında bulunmaktadır (Şekil 1). Türkiye'nin yetişme ortamı bölgelerinden İç Anadolu Bölgesi, Batı İç Anadolu yetişme ortamı bölgesi içerisinde kalmaktadır (Kantarcı 2005). 1/500.000 ölçekli Türkiye Jeoloji Haritası'nın Ankara paftası içerisinde kalan araştırma alanında dasit, riyolit, bazalt, volkanik tüf, aglomera, breş, kuvarsit, mikaşist ve kireçtaşı anakayalar yaygin olarak bulunmaktadır (Pamir ve Erentöz 1975). En yaygın toprak tipi esmer orman toprağıdır (Güner ve ark. 2011).

İklim değerlendirmelerinde ağaçlandırma alanlarına en yakın mesafede bulunan Eskişehir, Mihalıççık, Sivrihisar, Emirdağ, Dinar ve Çay meteoroloji istasyonu verileri kullanılmıştır. Meteoroloji istasyonu verilerine göre yıllık ortalama yüksek sicaklık $21,5-22,0{ }^{\circ} \mathrm{C}$, yıllık ortalama s1- 
caklık $10,8-11,1{ }^{0} \mathrm{C}$, yıllık yağış ise $374,2-435,5$ $\mathrm{mm}$ arasında değişmektedir. Erinç yöntemine göre iklim tipleri Tablo 1'de verilmiştir (Özyuvacı
1999). Tablo 1 incelendiğinde deneme alanlarının tamamına yakınının yarı nemli iklim tipine sahip olduğu görülmektedir.

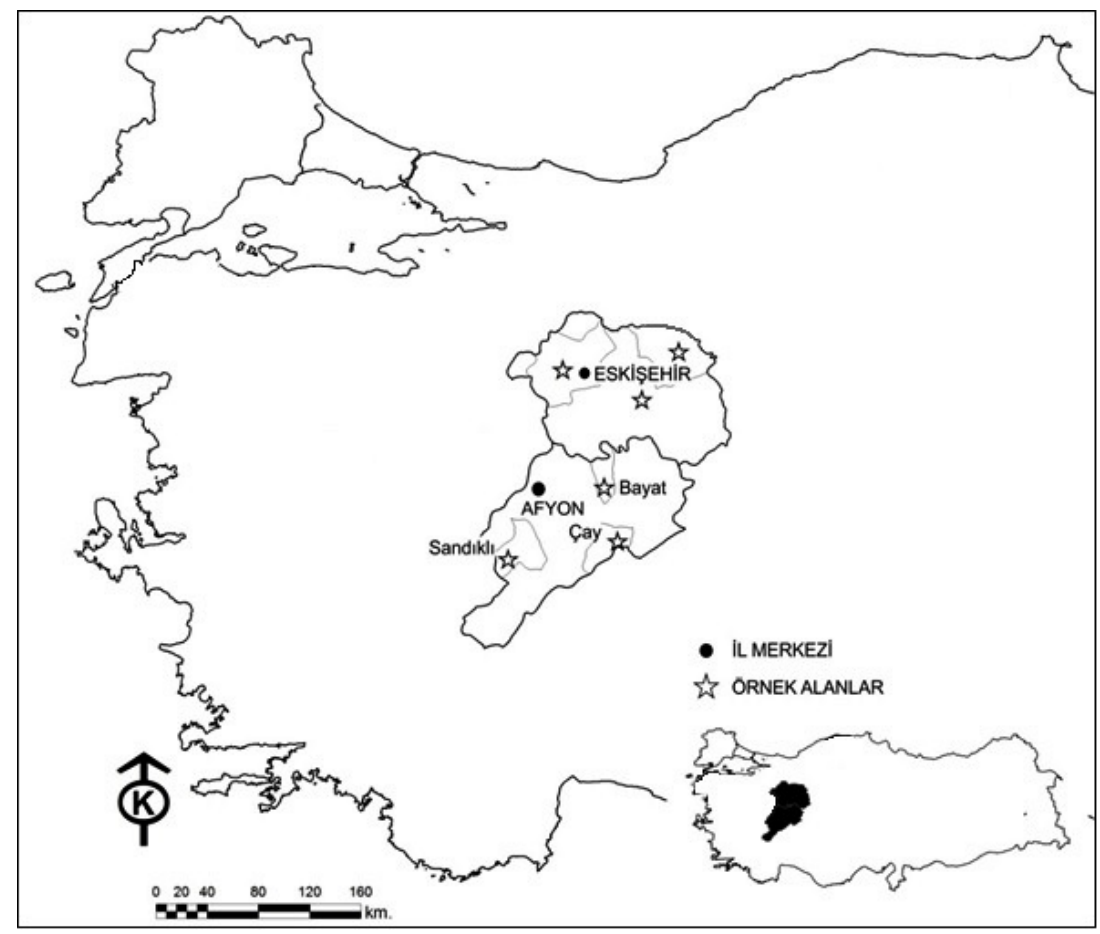

Şekil 1. Araştırma alanlarının konumu Figure 1. Location of the study areas

Tablo 1. Araştırma alanlarının Erinç yöntemine göre iklim tipleri Table 1. Climate types of the study area according to Erinc method

\begin{tabular}{|c|c|c|c|c|c|}
\hline İli & İlçesi & Ağaçlandırma sahası & $\begin{array}{l}\text { Yükselti } \\
\text { (m) }\end{array}$ & $\begin{array}{l}\text { Yağış etkenliği } \\
\text { indisi } \\
\text { (Im) }\end{array}$ & İklim tipi \\
\hline Eskişehir & Merkez & Musaözü, Kocakır, İmişehir, Kalabak & 900 & 25,9 & Yar1 nemli \\
\hline Eskişehir & Sivrihisar & Kaymaz & 1100 & 24,1 & Yar1 nemli \\
\hline Eskişehir & Mihalıççık & Ormantepe, Kizıldağ & 1100 & 26,4 & Yar1 nemli \\
\hline Eskişehir & Mihalıççık & Ormantepe & 1300 & 37,5 & Yarı nemli \\
\hline Afyonkarahisar & Çay & Çayderesi, Dortderesi & 1300 & 28,8 & Yarı nemli \\
\hline Afyonkarahisar & Çay & Çayderesi, Dortderesi & 1500 & 34,8 & Yar1 nemli \\
\hline Afyonkarahisar & Emirdağ1 & Köroğlubeli & 1300 & 36,4 & Yar1 nemli \\
\hline Afyonkarahisar & Emirdağ1 & Köroğlubeli & 1500 & 46,2 & Nemli \\
\hline Afyonkarahisar & Sand1kl1 & Kestel & 1100 & 31,2 & Yar1 nemli \\
\hline
\end{tabular}

\subsection{Arazi Çalıșmaları}

Örneklemeler, 6 meşcere tipinden ( $\mathrm{Sa}, \mathrm{Sa} 3, \mathrm{Sb}$, $\mathrm{Sb} 3, \mathrm{Sc} 2$ ve $\mathrm{Sc} 3$ ) ve her meşcere tipinden 5-8 arasında olmak üzere toplam 40 alanda yapılmıştır (Tablo 2). Örnek alanlar kare veya dikdörtgen şeklinde ve içerisine en az 15 adet fert girecek büyüklükte alınmıştır (Çepel ve ark. 1977). Daha sonra bir adet toprak çukuru açılmış ve bu toprak çukurundaki kesitte mineral toprak horizonları ayrılarak genetik toprak tipi belirlenmiştir. Toprak ve yetișme ortamı arazide tanımlandıktan sonra, ayrılan toprak horizonlarından 1 litre hacmindeki silindir ile toprak örnekleri alınmıştır (Kantarcı 2000, Kantarc1 2005).

Ölü örtü örnekleri, örnek alanı temsil eden ve her biri 1/4 m² (50x50 cm) büyüklüğündeki 4 farklı kısmından alınmıştır (Kantarc1 2005). Örnek alandaki diri örtünün çalı kısmı 4 m² (2x2 m) ve ot kıs$\mathrm{m} 1 \mathrm{~m}^{2}(1 \mathrm{x} 1 \mathrm{~m})$ alanda kökleri ile birlikte sökülerek çıkartılmış ve yıkanarak topraklarından arındırıl- 
mıştır. Daha sonra kök boğazlarından kesilerek toprak üstü ve toprak altı kısımlarının tamamı ayrı ayrı tartılmıştır. Ayrıca diri örtünün örnek alanı kaplama oranı (\%) hem çalı hem de ot kısmı için ayrı ayrı tahmin edilmiştir.

Örnek alanlardaki tüm fertlerin göğüs yüksekliğindeki çap $\left(\mathrm{d}_{1,3}\right)$ ve boyları $(\mathrm{h})$ ölçülmüştür. Sa meşcerelerinde dip çap, $\mathrm{Sa}_{3}$ meşcerelerinde ise dip çap ile birlikte gögüs yüksekliğindeki çap ölçümleri de yapılmıştır. Farklı çap ve boy kademelerine dağılacak şekilde her örnek alandan sağlıklı, tepesi ve dalları kırılmamış, baskı altında kalmamış bir fert kesilmiştir. Kesilen ağacın boyu cm hassasiyetinde ölçülüp, dip kütükte yaş say1mı yapılmıştır. Daha sonra kesilen ağacın dalları temizlenip, gövde 2 m'lik bölümlere ayrılarak, her bölümün çift yönlü kabuklu-kabuksuz çapları ölçülmüş, ağırlıkları $50 \mathrm{~g}$ hassasiyetli askılı terazi ile tartılmış ve nem içeriklerini belirlemek amaciyla her seksiyonun ortasından yaklaşık $5 \mathrm{~cm}$ kalınlığında diskler alınmıştır. İbreler yaş farkı gözetilmeksizin dallardan ayrıldıktan sonra kümelenip; ibre, kuru dal ve canlı dal ağırlıkları ayrı ayrı tartılmıştır.

Örnek alanlardan kesilen her ferdin kökü kazma, balta, motorlu testere ve calaskar yardımıyla sökülmüş ve en yakın şehir merkezine taşınmıştır. Burada kökler basınçlı su ile yıkanarak taş ve topraklarından arındırılmıştır. Daha sonra kökler üç çap grubuna $(<1 \mathrm{~cm}, 1-4 \mathrm{~cm}$ ve $>4 \mathrm{~cm})$ ayrılarak (Ranger ve Gelhaye 2001) tartılmıştır.

Laboratuvarda nem ve karbon tayini için, kök $(<1$ $\mathrm{cm}, 1-4 \mathrm{~cm}$ ve $>4 \mathrm{~cm})$, gövde $(5 \mathrm{~cm}$ kalınlığındaki diskler), dal (kuru ve canlı), ibre ve diri örtüden alınan alt örnekler arazide $0,01 \mathrm{~g}$ hassasiyetle tart1larak taze ağırlıkları belirlenmiştir.

Tablo 2. Araştırma alanındaki meşcerelere ait bazı özellikler

Table 2. Some characteristics of the stands studied

\begin{tabular}{|c|c|c|c|c|c|c|c|}
\hline $\begin{array}{c}\text { Meșcere } \\
\text { Tipi }\end{array}$ & $\begin{array}{c}\text { Örnek } \\
\text { Alan } \\
\text { Adedi }\end{array}$ & $\begin{array}{c}\text { Cap } \\
\left(\mathrm{d}_{0}-\mathrm{cm}\right) \\
\text { Ort } \pm \mathrm{SH} \\
\end{array}$ & $\begin{array}{c}\text { Çap } \\
\left(\mathrm{d}_{1,3}-\mathrm{cm}\right) \\
\text { Ort } \pm \mathrm{SH}\end{array}$ & $\begin{array}{c}\text { Boy } \\
(\mathrm{m}) \\
\text { Ort } \pm \text { SH }\end{array}$ & $\begin{array}{c}\text { Yaş } \\
\text { Ort } \pm \text { SH }\end{array}$ & $\begin{array}{c}\text { Kbl Hacim } \\
\left(\mathrm{m}^{3} / \mathrm{ha}\right) \\
\text { Ort } \pm \mathrm{SH}\end{array}$ & $\begin{array}{c}\text { Ağaç Sayis } \\
\text { (adet/ha) } \\
\text { Ort } \pm \text { SH }\end{array}$ \\
\hline $\mathrm{Sa}$ & 5 & $8,98 \pm 0,99$ & $4,55 \pm 0,94$ & $2,89 \pm 0,42$ & $19 \pm 3,07$ & $8,647 \pm 1,617$ & $908 \pm 181$ \\
\hline $\mathrm{Sa} 3$ & 4 & $12,10 \pm 0,38$ & $6,20 \pm 0,35$ & $3,90 \pm 0,19$ & $21 \pm 0,40$ & $22,343 \pm 3,060$ & $1697 \pm 241$ \\
\hline $\mathrm{Sb} 2$ & 7 & & $12,12 \pm 1,19$ & $6,64 \pm 0,65$ & $22 \pm 1,49$ & $53,030 \pm 7,779$ & $1178 \pm 73$ \\
\hline $\mathrm{Sb} 3$ & 8 & & $12,92 \pm 1,22$ & $7,66 \pm 0,80$ & $30 \pm 3,38$ & $99,151 \pm 16,209$ & $1885 \pm 168$ \\
\hline $\mathrm{Sc} 2$ & 8 & & $23,40 \pm 1,80$ & $13,54 \pm 0,76$ & $41 \pm 2,02$ & $241,743 \pm 37,798$ & $787 \pm 167$ \\
\hline $\mathrm{Sc} 3$ & 8 & & $26,04 \pm 1,14$ & $15,52 \pm 1,06$ & $42 \pm 1,48$ & $349,155 \pm 54,065$ & $1008 \pm 87$ \\
\hline
\end{tabular}

\subsection{Laboratuvar Çalışmaları}

Araziden alınan canlı bitkisel kütleye ait alt örnekler (kök, gövde, dal, ibre ve diri örtü) laboratuvarda etüvlere alınarak $65{ }^{\circ} \mathrm{C}$ 'de sabit ağırlığa kadar kurutulduktan sonra tartılıp nem içerikleri belirlenmiştir. Bu nem içerikleri kullanılarak tek ağaç için gövde odunu, kabuk, canlı dal, kuru dal ve ibrelerin kuru ağırlıkları hesaplanmıştır. Ayrıca birim alandaki diri örtü kuru ağırlıkları da belirlenmiştir. Ağaçların kabuk miktarının hesaplanması için gövdeden alınan disklerin kabuklu ağırlığı tartıldıktan sonra kabuklar soyulmuş ve disklerin kabuksuz ağırlıkları tekrar tartılarak aradaki farktan kabuk ağırlığı bulunmuştur. Kabuk ağırlığ $1 /$ kabuklu disk ağırlığı oranından tüm ağaç gövdesinin kabuk miktarı hesaplanmıştır.

Ölü örtü örneklerinin tamamı $65{ }^{\circ} C^{\prime}$ de sabit ağırlığa kadar kurutulduktan sonra tartılmış ve birim alandaki miktarı bulunmuştur. Daha sonra öğütülen tüm bitkisel örnekler $65{ }^{\circ} \mathrm{C}$ 'de kurutulmuş ve kuru yakma yöntemi ile Leco Truspec $\mathrm{CNH}$ ciha- zında karbon içerikleri belirlenmiştir.

Araziden alınan toprak örnekleri hava kurusu hale gelene kadar tavalarda bekletilmiş ve tartılarak hava kurusu hacim ağırlığı belirlenmiştir. Daha sonra ögütülerek 2 mm'lik elekten geçirilmiştir. Eleğin üzerinde kalan taş kısmı yıkanarak yüzeylerine yapışmış toprak parçalarından uzaklaştırılmış ve tekrar hava kurusu hale gelene kadar bekletilerek tartılmıştır. Hava kurusu hacim ağırlığından, hava kurusu taş ağırlığı düşülerek ince toprağın $(Ø<2 \mathrm{~mm})$ hacim ağırlığı belirlenmiştir. Öğ̈üülen ince toprakların bir kısmı $105{ }^{\circ} \mathrm{C}$ 'de sabit ağırlığa kadar kurutulduktan sonra tartılıp nem içerikleri belirlenmiş ve bu nem içeriklerinden yararlanılarak ince toprak kısmının mutlak kuru hacim ağırlığı hesaplanmıştır.

\subsection{Değerlendirme}

Bu çalışmada, çap (a meşcerelerinde $d_{0}=$ dip çap, b ve c meşcerelerinde $d_{1,3}=$ gögüs yüksekliğindeki çap kullanılmıştır) ve ağaç boyu (h) bağımsız değişken, 
ağaç bileşenleri kütlesinin bağımlı değişken olduğu aşağıdaki denklemler geliştirilmiştir:

$$
\begin{array}{ll}
K_{i}=a+b x & \text { (Doğrusal-Linear) } \\
K_{i}=a+b x+c x^{2} & \text { (Eğrisel-Quadratic) } \\
K_{i}=a x^{b} & \text { (Üs-Power) } \\
K_{i}=a b^{x} & \text { (Compound) } \\
K_{i}=e^{[a-b(d o)]} & \text { (S) }
\end{array}
$$

Denklemlerde $K=$ kütle (kg/ağaç), $i=$ ağaç bileşenleri (ibre, kuru dal, canlı dal, kabuksuz gövde, kabuk, kabuklu gövde, toprak üstü ağaç kütlesi, kök, toplam ağaç kütlesi), $x$ = bağımsız değişkenler (d, $\left.\mathrm{h}, \mathrm{d}^{2} \mathrm{~h}\right), \mathrm{a}, \mathrm{b}$ ve $\mathrm{c}=$ denklem katsayılarıdır.

Ağaç bileşenleri kütlesini tahmin etmek için geliştirilen denklemler kullanılarak örnek alanlardaki toplam ağaç bileşenleri kütlesi hesaplanmıştır. Bu değerler hektara çevirme katsayısı ile çarpılarak örnek alanların 1 hektar alandaki ağaç bileşenleri kütlesi bulunmuştur.

Ağaç karbon stoğunun belirlenmesi için, örnek alanların hektardaki ibre, kuru dal ve canlı dal kütlesi ile analiz sonucu elde edilen karbon oranları çarpılarak 1 hektar alandaki ibre, kuru dal ve canlı dal karbon miktarı hesaplanmıştır. Tek ağaçlara ait kabuksuz gövde, kabuk ve kök örneklerinde birden fazla alt örnek alındığ 1 için karbon oranlarının belirlenmesinde ağırlıklı ortalama esas alınmıştır. Kabuksuz gövde, kabuk ve kök örneklerinde ağırlıklı olarak hesaplanan karbon oranları ile hektardaki kütleleri çarpılarak bir hektar alandaki kabuksuz gövde, kabuk ve kök karbon miktarı hesaplanmıştır. Daha sonra ibre, kuru dal, canlı dal, kabuksuz gövde, kabuk ve kök karbon miktarları toplanarak örnek alanların bir hektar alandaki ağaç karbon stoğu hesaplanmıştır. Ayrıca, bir ağaca ait karbon stoğunun, kuru ağaç kütlesine bölünmesi ile ağaç kütlesine ait ağırlıklı karbon oranı belirlenmiştir.

Yine, ölü örtü ve diri örtünün örnek alandaki miktarı, analizler ile bulunan karbon oranları ile çarpılarak örnek alandaki karbon miktarı bulunmuş, daha sonra bu değerler 1 hektar alana dönüştürülmüştür.

Topraktaki yüzde karbon değerleri ait olduğu horizonun ince toprak miktarı (g/l) ile çarpılarak, 1 litre hacimdeki karbon miktarı bulunmuştur. Daha sonra bu değerler horizon kalınlığ 1 (mm) ile çarpılarak horizonlardaki karbon miktarı, horizonlardaki karbon miktarlarının toplanmasıyla da $1 \mathrm{~m}$ derinlik ve $1 \mathrm{~m}^{2}$ alandaki (pedon) karbon miktarı hesaplanmıştır. Bu değer de 10.000 ile çarpılmak suretiyle örnek alanların hektardaki karbon değerleri bulunmuştur.
Hacim ağırlığı, kök/sak oranı, bitkisel kütle genişletme katsayıları, bitkisel kütle genişletme ve dönüştürme katsayılarının belirlenmesinde aşağıdaki formüller kullanılmıştır.

$$
\begin{aligned}
& H A=K_{K B L G O ̈ V D E} / V_{K B L} \\
& k o ̈ k / s a k \text { oranı }=K_{\text {KÖK }} / K_{\text {TOPRAKÜSTÜ }} \\
& B G K_{\dot{I}}=K_{\dot{I}} / K_{\text {KBLGÖVDE }} \\
& B D G K_{\dot{I}}=K_{\dot{I}} / V_{K B L}
\end{aligned}
$$

Formüllerde, $H A$ hacim ağırlığı $\left(\mathrm{t} / \mathrm{m}^{3}\right), K_{K B L G O ̈ V D E}$ kabuklu gövde odunu kütlesi (t/ağaç), $V_{K B L}$ kabuklu gövde odunu hacmi (m³/ağaç), $K_{K O ̈ K}$ kök kütlesi (t/ ağaç), $K_{\text {TOPRAKÜSTÜ }}$ toprak üstü ağaç kütlesi (t/ağaç), $B G K$ bitkisel kütle genişletme katsayısı, $B D G K$ bitkisel kütle dönüştürme ve genişletme katsayısı (t/ $\mathrm{m}^{3}$ ) ve $K$ bitkisel kütle (t/ağaç), ${ }_{i}$ ağaç bileşenleridir (ibre, kuru dal, canlı dal, kabuksuz gövde, kabuk, kabuklu gövde, toprak üstü kütle, kök ve toplam kütle).

Kütle denklemlerinin geliştirilmesinde regresyon analizlerinden yararlanılmıştır. Regresyon analizleri sonucunda standart hatası en küçük ve ilişki katsayısı $\left(\mathrm{R}^{2}\right)$ en yüksek olan modeller tercih edilmiştir. Meşcere tiplerine göre ekosistemin farklı bileşenlerinin (ağaç, diri örtü, ölü örtü ve toprak) kütlesi, karbon oranlar1 ve karbon stoklar1 arasındaki farklılıklar tek yönlü varyans analizi ile değerlendirilmiştir. Varyans analizi sonucunda istatistiksel bakımdan anlamlı $(P<0,05)$ farkl11ıklar bulunması durumunda Duncan testi uygulanarak homojen (benzer) gruplar oluşturulmuştur (Kalıpsiz 1994, Özdamar 2002).

\section{Bulgular}

\subsection{Kütle denklemleri}

İbre, canlı dal, toprak üstü ve toplam ağaç kütlesinin tahmininde compound $\left(y=a b^{x}\right)$; kuru dal, gövde, kabuk ve kök kütlesinin tahmininde ise power $\left(\mathrm{y}=a x^{b}\right)$ modeli en iyi tahmini sağlamıştır. İbre, canlı dal, kabuklu gövde, kabuksuz gövde, kabuk, toprak üstü, kök ve toplam ağaç kütlesini $\mathrm{d}_{1,3}$; kurudal kütlesini ise $\mathrm{d}_{1,3}{ }^{2} \mathrm{~h}$ indeksi en iyi tahmin etmiştir (Tablo 3).

\subsection{HA, BGK, BDGK ve kök/sak oranı}

Hacim ağırlığı (HA), bitkisel kütle genişletme katsayısı (BGK), bitkisel kütle dönüştürme ve genişletme katsayısı (BDGK) ile kök/sak oranlarının (kök kütlesi/toprak üstü kütle) meşcere tiplerine göre değişimine ait varyans analizi Tablo 4'te verilmiştir. BGK TOPRAKÜSTÜ ve BDGK TOPRAKÜStÜ $_{\text {bak1- }}$ mından meşcere tipleri arasında $P<0,001$ önem dü- 
zeyinde farklılıklar belirlenirken; HA ve kök/sak oranı bakımından önemli bir farklılık belirlenememiştir $(P>0,05)$. Sedir için ortalama HA 0,467 t/

$\mathrm{m}^{3}$, kök/sak oranı 0,207, BGK $_{\text {TOPRAKÜstÜ }} 1,635$ ve BDGK $_{\text {TOPRAKÜSTÜ }} 0,762 \mathrm{t} / \mathrm{m}^{3}$ olarak bulunmuştur.

Tablo 3. Tek ağaç bileşeni kütlelerinin regresyon modelleri

Table 3. Regression models for single tree component biomass

\begin{tabular}{|c|c|c|c|c|c|c|c|}
\hline \multirow{2}{*}{ Denklemler } & \multirow{2}{*}{$\mathrm{R}^{2}$} & \multirow{2}{*}{ SH } & \multirow{2}{*}{ F oran1 } & \multirow{2}{*}{$P$} & \multicolumn{3}{|c|}{ Denklem katsayıları } \\
\hline & & & & & $\mathrm{a}$ & $\mathrm{b}$ & $\mathrm{c}$ \\
\hline \multicolumn{8}{|c|}{ Ağaçlar } \\
\hline$K_{i B R E}=a b^{(d l, 3)}$ & 0,640 & 0,45 & 65,718 & 0,000 & $3,116^{* * *}$ & $1,065^{* * *}$ & \\
\hline$K_{\text {KURUDAL }}=a\left(d_{1,3}{ }^{2} h\right)^{b}$ & 0,813 & 0,69 & 139,107 & 0,000 & $0,002^{\mathrm{ns}}$ & $0,944^{* * *}$ & \\
\hline$K_{C A N L I D A L}=a b^{(d l, 3)}$ & 0,801 & 0,48 & 149,298 & 0,000 & $2,383^{* * *}$ & $1,107^{* * *}$ & \\
\hline$K_{K B L G O ̈ V D E}=a\left(d_{1,3}\right)^{b}$ & 0,984 & 0,19 & 2267,898 & 0,000 & $0,047^{* * *}$ & $2,488^{* * *}$ & \\
\hline$K_{K B S G O ̈ V D E}=a\left(d_{1,3}\right)^{b}$ & 0,984 & 0,19 & 2345,310 & 0,000 & $0,031^{* * *}$ & $2,566^{* * *}$ & \\
\hline$K_{K A B U K}=a\left(d_{1,3}\right)^{b}$ & 0,975 & 0,20 & 1458,747 & 0,000 & $0,021^{* * *}$ & $2,144^{* * *}$ & \\
\hline$K_{\text {TOPRAKÜSTÜ }}=a b^{(d l, 3)}$ & 0,973 & 0,20 & 1323,558 & 0,000 & $7,818^{* * *}$ & $1,136^{* * *}$ & \\
\hline$K_{K O ̈ K}=a\left(d_{1,3}\right)^{b}$ & 0,939 & 0,30 & 571,018 & 0,000 & $0,066^{* * *}$ & $2,001^{* * *}$ & \\
\hline$K_{\text {TOPLAM }}=a b^{(d l, 3)}$ & 0,971 & 0,21 & 1224,290 & 0,000 & $0,105^{* * *}$ & $0,881^{* * *}$ & \\
\hline \multicolumn{8}{|c|}{ Fidanlar } \\
\hline$K_{\text {IBRE }}=a\left(d_{0}\right)^{b}$ & 0,938 & 0,32 & 19,756 & 0,000 & $0,024^{\mathrm{ns}}$ & $2,222^{* *}$ & \\
\hline$K_{C A N L I D A L}=a\left(d_{0}^{2} h\right)^{b}$ & 0,963 & 0,11 & 128,578 & 0,000 & $0,067^{*}$ & $0,715^{* * *}$ & \\
\hline$K_{K B S G \ddot{O V D E}}=a\left(d_{0}{ }^{2} h\right)^{b}$ & 0,965 & 0,15 & 191,334 & 0,000 & $0,009^{\text {ns }}$ & $0,972^{* * *}$ & \\
\hline$K_{K A B U K}=a\left(d_{0}{ }^{2} h\right)^{b}$ & 0,945 & 0,13 & 120,235 & 0,000 & $0,017^{*}$ & $0,686^{* * *}$ & \\
\hline$K_{K B L G \ddot{O} V D E}=a-b\left(d_{0}^{2} h\right)+c\left(d_{0}^{2} h\right)^{2}$ & 0,974 & 0,00 & 112,674 & 0,000 & $-0,002^{\mathrm{ns}}$ & $0,00003499^{* * *}$ & $-1,567 \mathrm{E}-008^{* * *}$ \\
\hline$K_{\text {TOPRAKÜSTÜ }}^{\text {KELGUVDE }}=a\left(d_{0}\right)^{b}$ & 0,871 & 0,22 & 47,452 & 0,000 & $0,058^{\mathrm{ns}}$ & $2,306^{* * *}$ & \\
\hline$K_{K O ̈ K}=a\left(d_{0}\right)^{b}$ & 0,760 & 0,32 & 22,163 & 0,000 & $0,012^{\mathrm{ns}}$ & $2,288^{* *}$ & \\
\hline$K_{\text {TOPLAM }}=a\left(d_{0}\right)^{b}$ & 0,858 & 0,23 & 42,441 & 0,000 & $0,071^{\mathrm{ns}}$ & $2,303^{* * *}$ & \\
\hline
\end{tabular}

$K=$ kütle (kg/ağaç), $d_{1,3}=$ göğüs yüksekliğindeki çap (cm), $d_{0}=$ dip çap (cm) $h=$ boy (m), $\mathrm{R}^{2}=$ ilişki katsayısı, $\mathrm{SH}=$ standart hata, $P:$ önem düzeyi, ns: önemsiz, ${ }^{* *}: P<0,01,{ }^{* * *}: P<0,001$

Tablo 4. HA $\left(\mathrm{t} / \mathrm{m}^{3}\right)$, BGK, BDGK $\left(\mathrm{t} / \mathrm{m}^{3}\right)$ ve kök/sak oranlarının meşcere tiplerine göre değişimi Table 4. Wood densities (HA), Biomass expansion factors (BGF), Biomass expansion and conversion factors (BDGF) and root to shoot ratios

\begin{tabular}{|c|c|c|c|c|c|c|c|}
\hline \multirow{2}{*}{ Parametreler } & \multicolumn{5}{|c|}{ Mesçere tipleri } & \multirow{2}{*}{$\mathrm{Ort} \pm \mathrm{SH}$} & \multirow{2}{*}{$P$} \\
\hline & $\mathrm{a} / \mathrm{a} 3^{*}$ & b2 & b3 & $\mathrm{c} 2$ & c3 & & \\
\hline $\mathrm{HA}\left(\mathrm{t} / \mathrm{m}^{3}\right)$ & $0,508 \pm 0,044$ & $0,453 \pm 0,010 \mathrm{a}$ & $0,461 \pm 0,010 \mathrm{a}$ & $0,476 \pm 0,016 \mathrm{a}$ & $0,475 \pm 0,030 \mathrm{a}$ & $0,467 \pm 0,009$ & $P>0,05$ \\
\hline Kök/sak & $0,205 \pm 0,010$ & $0,222 \pm 0,013 \mathrm{a}$ & $0,196 \pm 0,009 \mathrm{a}$ & $0,234 \pm 0,021 \mathrm{a}$ & $0,179 \pm 0,015 \mathrm{a}$ & $0,207 \pm 0,008$ & $P>0,05$ \\
\hline BGK $_{\text {TOPRAKÜSTŨ }}$ & $3,125 \pm 0,209$ & $1,996 \pm 0,117 \mathrm{~b}$ & $1,674 \pm 0,109 \mathrm{a}$ & $1,518 \pm 0,045 \mathrm{a}$ & $1,396 \pm 0,046 \mathrm{a}$ & $1,635 \pm 0,056$ & $P<0,001$ \\
\hline BDGK $_{\text {TOPRAKÜSTU }}$ & $1,631 \pm 0,238$ & $0,906 \pm 0,060 \mathrm{~b}$ & $0,770 \pm 0,046 \mathrm{ab}$ & $0,726 \pm 0,044 \mathrm{ab}$ & $0,664 \pm 0,050 \mathrm{a}$ & $0,762 \pm 0,028$ & $P<0,001$ \\
\hline
\end{tabular}

Satırlardaki aynı harfler aralarında fark bulunmayan $(P>0,05)$ benzer grupları göstermektedir, HA: hacim ağırlı̆̆ $\left.1 \mathrm{t} / \mathrm{m}^{3}\right)$, kök/ sak oranı: kök kütlesi/toprak üstü ağaç kütlesi, BGK: bitkisel kütle genişletme katsayısı, BDGK: bitkisel kütle dönüştürme ve genişletme katsayısı $\left(\mathrm{t} / \mathrm{m}^{3}\right)$, *a meşcerelerine ait katsayılar karşılaştırmalara dahil edilmemiş olup, bilgi amacıyla verilmiştir. $P$ :önem düzeyi

\subsection{Karbon oranları}

Ağaç bileşenleri karbon içeriklerinin meşcere tiplerine göre değişimine ait varyans analizi sonuçları Tablo 5'te verilmiştir. İbre ve kabuk karbon oranları meşcere tipleri arasında $(P<0,05)$, kabuksuz gövde, toprak üstü ağaç kütlesi ve toplam ağaç kütlesi ise $(P<0,01)$ önemli düzeyde farklılıklar göstermiştir. Canlı dal ve kök karbon oranları ise meşcere tipleri arasında anlamlı bir farklılık gös- 
termemiştir $(P>0,05)$. Karbon oranları ibrede Sa, kabuksuz gövdede $\mathrm{Sb3}, \mathrm{Sc} 2$ ve $\mathrm{Sc} 3$, kabukta $\mathrm{Sb}$, $\mathrm{Sb} 3$ ve $\mathrm{Sc} 2$, toprak üstü ağaç kütlesinde $\mathrm{Sc} 3$ ve toplam ağaç kütlesinde ise $\mathrm{Sc} 3$ meşcerelerinde daha yüksek düzeyde bulunmuştur. Bu bulgular genel olarak değerlendirildiğinde, c meşcerelerindeki karbon oranları a ve b meşcerelerinden daha yüksektir. Tablo 5'te ayrıca karbon oranlarının ağaç bileşenlerine göre değişimi de incelenmiştir. Buna göre, ağaç bileşenlerinin karbon oranları arasındaki farklılıklar istatistiksel bakımdan önemli bulun- muştur $(P<0,001)$. En yüksek karbon oranı gövde odunu ve kabukta, en düşük karbon oranı ise kökte tespit edilmiştir.

Ot ve çalı (alıç, kuşburnu, ardıç) bileşenleri karbon oranları meşcere tiplerine arasında önemli bir farklılık göstermemiştir $(P>0,05)$. Ölü örtü karbon oranları mesçere tipleri arasında önemli farklılıklar göstermiş olup $(P<0,001)$, a3 mesçerelerinde \%45,9 olan karbon oranı kademeli bir düşüşle c3 mesçerelerinde \%36,8'e inmiştir (Tablo 5).

Tablo 5. Karbon oranlarındaki değişimler (\%, ortalama $\pm \mathrm{SH})$

Table 5. Changes in carbon concentrations of biomass compartments

\begin{tabular}{|c|c|c|c|c|c|c|c|c|}
\hline & \multicolumn{6}{|c|}{ Meşcere tipleri } & \multirow{2}{*}{$\begin{array}{c}\text { Önem } \\
\text { düzeyi } \\
(P)\end{array}$} & \multirow{2}{*}{$\begin{array}{l}\text { Ort } \pm \text { SH } \\
P<0,001\end{array}$} \\
\hline & $\mathrm{a}$ & a3 & b2 & b3 & $\mathrm{c} 2$ & c3 & & \\
\hline \multicolumn{9}{|c|}{ Ağaç bileșenleri } \\
\hline İbre & $51,6 \pm 0,5 \mathrm{~b}$ & $51,5 \pm 0,2 \mathrm{ab}$ & $51,0 \pm 0,3 \mathrm{ab}$ & $51,2 \pm 0,2 \mathrm{ab}$ & $50,7 \pm 0,2 \mathrm{a}$ & $51,0 \pm 0,1 \mathrm{ab}$ & $P<0,05$ & $51,1 \pm 0,1 \mathrm{~b}^{\mathrm{A}}$ \\
\hline Kuru dal* & $50,9 \pm 0,0$ & $51,7 \pm 01$ & $50,7 \pm 0,2$ & $50,8 \pm 0,3$ & $50,6 \pm 0,3$ & $51,7 \pm 0,2$ & & $51,0 \pm 0,1 \mathrm{~b}$ \\
\hline Canlı dal & $51,6 \pm 0,4 \mathrm{a}$ & $51,3 \pm 0,1 \mathrm{a}$ & $51,5 \pm 0,1 \mathrm{a}$ & $51,7 \pm 0,1 \mathrm{a}$ & $51,6 \pm 0,2 \mathrm{a}$ & $51,7 \pm 0,1 \mathrm{a}$ & $P>0,05$ & $51,6 \pm 0,1 \mathrm{c}$ \\
\hline Kbz gövde & $51,5 \pm 0,2 \mathrm{ab}$ & $51,6 \pm 0,5 \mathrm{ab}$ & $50,9 \pm 0,3 \mathrm{a}$ & $51,8 \pm 0,1 \mathrm{~b}$ & $52,1 \pm 0,2 \mathrm{~b}$ & $52,2 \pm 0,1 \mathrm{~b}$ & $P<0,01$ & $51,7 \pm 0,1 \mathrm{c}$ \\
\hline Kabuk & $50,8 \pm 0,7 \mathrm{a}$ & $51,5 \pm 0,4 \mathrm{ab}$ & $52,2 \pm 0,2 \mathrm{~b}$ & $52,0 \pm 0,1 \mathrm{~b}$ & $52,0 \pm 0,3 \mathrm{~b}$ & $51,4 \pm 0,1 \mathrm{ab}$ & $P<0,05$ & $51,7 \pm 0,1 \mathrm{c}$ \\
\hline Toprak üstü $^{* *}$ & $51,4 \pm 0,3 \mathrm{ab}$ & $51,4 \pm 0,2 \mathrm{ab}$ & $51,2 \pm 0,1 \mathrm{a}$ & $51,6 \pm 0,1 \mathrm{ab}$ & $51,9 \pm 0,2 \mathrm{bc}$ & $52,1 \pm 0,1 \mathrm{c}$ & $P<0,01$ & $51,7 \pm 0,1 \mathrm{c}$ \\
\hline Kök & $49,4 \pm 0,4 \mathrm{a}$ & $49,4 \pm 0,2 \mathrm{a}$ & $49,6 \pm 0,1 \mathrm{a}$ & $49,4 \pm 0,2 \mathrm{a}$ & $49,0 \pm 0,2 \mathrm{a}$ & $49,4 \pm 0,1 \mathrm{a}$ & $P>0,05$ & $49,3 \pm 0,1 \mathrm{a}$ \\
\hline Toplam** & $51,1 \pm 03$ a & $51,0 \pm 0,2 \mathrm{a}$ & $50,9 \pm 0,1 \mathrm{a}$ & $51,3 \pm 0,9 \mathrm{ab}$ & $51,4 \pm 0,2 \mathrm{ab}$ & $51,7 \pm 0,1 \mathrm{~b}$ & $P<0,01$ & $51,3 \pm 0,1 \mathrm{~b}$ \\
\hline \multicolumn{9}{|c|}{ Ot bileşenleri } \\
\hline Ot gövde & $43,1 \pm 0,8 \mathrm{a}$ & $41,1 \pm 3,2 \mathrm{a}$ & $40,9 \pm 1,8 \mathrm{a}$ & $41,8 \pm 1,3 \mathrm{a}$ & $41,9 \pm 0,2 \mathrm{a}$ & - & $P>0,05$ & $41,7 \pm 0,8$ \\
\hline Ot kök & $31,5 \pm 2,3 \mathrm{a}$ & $33,3 \pm 1,9 \mathrm{a}$ & $29,0 \pm 3,9 \mathrm{a}$ & $30,1 \pm 4,4 \mathrm{a}$ & $36,5 \pm 1,5 \mathrm{a}$ & - & $P>0,05$ & $31,7 \pm 1,4$ \\
\hline Toplam** & $34,1 \pm 1,6$ a & $36,0 \pm 1,8 \mathrm{a}$ & $30,3 \pm 3,7 \mathrm{a}$ & $31,3 \pm 4,2 \mathrm{a}$ & $37,3 \pm 1,7 \mathrm{a}$ & - & $P>0,05$ & $33,4 \pm 1,4$ \\
\hline \multicolumn{9}{|c|}{ Ölü örtü bileşenleri } \\
\hline Ölü örtü & - & $45,9 \pm 0,8 \mathrm{c}$ & $44,3 \pm 0,9 \mathrm{bc}$ & $42,7 \pm 0,9 \mathrm{bc}$ & $41,5 \pm 1,5 \mathrm{~b}$ & $36,8 \pm 1,9$ a & $P<0,001$ & $41,9 \pm 0,8$ \\
\hline \multicolumn{9}{|c|}{ Çalı bileşenleri } \\
\hline & Alıç & Kuşburnu & Ardıç & & & & & \\
\hline Çalı gövde & $48,53 \pm 1,48 \mathrm{a}$ & $47,92 \pm 0,47 \mathrm{a}$ & $49,03 \pm 0,02 \mathrm{a}$ & & & & $P>0,05$ & \\
\hline Çalı kök & $48,40 \pm 0,24 \mathrm{a}$ & $48,85 \pm 0,47 \mathrm{a}$ & $49,11 \pm 1,69 \mathrm{a}$ & & & & $P>0,05$ & \\
\hline Toplam** & $48,60 \pm 0,51 \mathrm{a}$ & $48,61 \pm 0,39$ a & $49,37 \pm 1,20 \mathrm{a}$ & & & & $P>0,05$ & \\
\hline
\end{tabular}

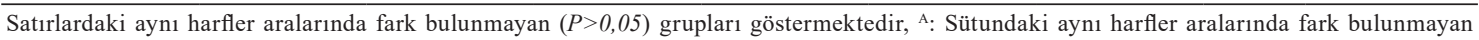
$(P>0,05)$ grupları göstermektedir, SH: standart hata, * kuru dala ait yeterli veri bulunmadığı için ortalamalara ait değerlendirme yapılamamıştır, **: ağırlıklı ortalama.

\subsection{Ekosistemdeki karbon stoğu}

Orman ekosistemlerinde karbon ağaçlarda, diri örtüde, ölü örtüde ve toprakta depolanmaktadır. Ağaç, diri örtü, ölü örtü ve toprak karbon stoklarının meşcere tiplerine göre değişimi Tablo 6'da verilmiştir. Sedir ağaçlandırma alanlarındaki toplam karbon stoğu meşcere tiplerine göre önemli farklılıklar göstermiştir $(P<0,001)$. Toplam karbon stoğu Sa3 meşcerelerinde en az (59,8 t/ha), Sc3 meşcerelerinde en fazla bulunmuştur (213 t/ha). Ekosistemdeki karbon stoklarının toplam karbon stoğuna oranı meşcere tiplerine göre farklılıklar göstermektedir. Sa meşcerelerinde ağaç kütlesi karbon stoğu, toplam karbon stoğunun \%7,4'ünü oluştururken bu oran Sc3 meşcerelerinde \%57,3'e kadar çıkmaktadır. Toprak karbon stoğunun toplam karbon stoğuna oranı, Sa meşcerelerinde \%90,1 iken bu oran Sc3 meşcerelerinde \%38,2'e kadar azalmaktadır. Diri örtü karbon stoklarının toplam karbon stoklarına katılma oranı oldukça düşük düzeydedir. Ölü örtü karbon stoğunun toplam karbon stoğuna katılma oranı ise \%3,7 ile \%6,1 arasında gerçekleşmiştir. Ortalama değerlere göre, sedir ağaçlandırma alanlarında toplam karbon stoğu 130,22 t/ha olarak bulunmuştur. 
Table 6. Ekosistemde karbon havuzlarının stok değișimi ( $\mathrm{C}$ t/ha, ortalama $\pm \mathrm{SH})$

Table 6. Stock changes in carbon pools of the ecosystem

\begin{tabular}{|c|c|c|c|c|c|c|c|c|}
\hline \multirow{2}{*}{$\begin{array}{c}\text { Karbon } \\
\text { havuzları }\end{array}$} & \multicolumn{6}{|c|}{ Mesçere tipleri } & \multirow{2}{*}{$P$} & \multirow{2}{*}{$\operatorname{Ort} \pm \mathrm{SH}$} \\
\hline & $\mathrm{a}$ & a3 & b2 & b3 & c2 & c3 & & \\
\hline \multicolumn{9}{|c|}{ Ağaç } \\
\hline İbre & $1,71 \pm 0,37 \mathrm{a}$ & $3,63 \pm 0,42 \mathrm{~b}$ & $3,59 \pm 0,41 b$ & $6,17 \pm 0,47 \mathrm{c}$ & $5,78 \pm 0,62 \mathrm{c}$ & $7,32 \pm 0,56 \mathrm{c}$ & $P<0,001$ & $5,11 \pm 0,35$ \\
\hline Kuru dal * & $0,01 \pm 0,01 \mathrm{a}$ & $0,09 \pm 0,06 \mathrm{a}$ & $0,85 \pm 0,28 \mathrm{a}$ & $1,61 \pm 0,3 \mathrm{a}$ & $4,02 \pm 0,63 b$ & $5,92 \pm 0,9 \mathrm{c}$ & $P<0,01$ & $2,47 \pm 0,41$ \\
\hline Canlı dal & $1,57 \pm 0,32 \mathrm{a}$ & $3,58 \pm 0,45 \mathrm{ab}$ & $4,66 \pm 0,8 \mathrm{ab}$ & $8,04 \pm 0,68 \mathrm{~b}$ & $13,92 \pm 2,18 \mathrm{c}$ & $16,65 \pm 1,86 \mathrm{c}$ & $P<0,001$ & $9,14 \pm 1,04$ \\
\hline Kbz gövde & $0,78 \pm 0,26 \mathrm{a}$ & $3,25 \pm 0,58 \mathrm{a}$ & $11,66 \pm 3,35 \mathrm{ab}$ & $20,72 \pm 3,03 b$ & $49,73 \pm 6,89 \mathrm{c}$ & $62,49 \pm 6,76 \mathrm{c}$ & $P<0,001$ & $29,11 \pm 4,22$ \\
\hline Kabuk & $0,25 \pm 0,06 \mathrm{a}$ & $0,95 \pm 0,16 \mathrm{a}$ & $2,66 \pm 0,66 \mathrm{ab}$ & $4,58 \pm 0,57 b$ & $8,18 \pm 0,97 \mathrm{c}$ & $10,27 \pm 0,94 \mathrm{c}$ & $P<0,001$ & $5,21 \pm 0,65$ \\
\hline Toprak üstü & $4,30 \pm 0,75 \mathrm{a}$ & $11,51 \pm 1,58 \mathrm{a}$ & $23,42 \pm 5,45 \mathrm{ab}$ & $41,12 \pm 4,77 \mathrm{~b}$ & $81,63 \pm 11,20 \mathrm{c}$ & $102,65 \pm 10,95 \mathrm{c}$ & $P<0,001$ & $51,05 \pm 6,59$ \\
\hline Kök & $0,58 \pm 0,14 \mathrm{a}$ & $2,16 \pm 0,35 \mathrm{ab}$ & $5,45 \pm 1,27 \mathrm{bc}$ & $9,35 \pm 1,11 \mathrm{c}$ & $15,05 \pm 1,75 \mathrm{~d}$ & $19,38 \pm 1,73 \mathrm{~d}$ & $P<0,001$ & $10,04 \pm 1,19$ \\
\hline Toplam & $\begin{array}{c}4,89 \pm 0,84 \mathrm{a} \\
(\% 7,4)\end{array}$ & $\begin{array}{c}13,67 \pm 1,92 \mathrm{a} \\
(\% 22,8)\end{array}$ & $\begin{array}{c}28,87 \pm 6,72 \mathrm{ab} \\
(\% 32,5)\end{array}$ & $\begin{array}{c}50,47 \pm 5,88 \mathrm{~b} \\
(\% 51,2) \\
\text { Çal1 } \\
\end{array}$ & $\begin{array}{c}96,68 \pm 12,92 \mathrm{c} \\
(\% 51,6)\end{array}$ & $\begin{array}{c}122,03 \pm 12,67 \mathrm{c} \\
(\% 57,3)\end{array}$ & $P<0,001$ & $61,08 \pm 7,77$ \\
\hline Gövde & & & $0,04 \pm 0,03 \mathrm{a}$ & & $0,45 \pm 0,25 \mathrm{a}$ & $0,61 \pm 0,40 \mathrm{a}$ & $P>0,05$ & $0,22 \pm 0,010$ \\
\hline Kök & & & $0,27 \pm 0,26 \mathrm{a}$ & & $2,79 \pm 2,03 \mathrm{a}$ & $1,18 \pm 0,77 \mathrm{a}$ & $P>0,05$ & $0,84 \pm 0,45$ \\
\hline Toplam & & & $\begin{array}{l}0,31 \pm 0,31 \mathrm{a} \\
\quad(\% 0,3)\end{array}$ & & $\begin{array}{c}3,24 \pm 2,16 \mathrm{a} \\
(\% 1,7)\end{array}$ & $\begin{array}{c}1,79 \pm 1,17 \mathrm{a} \\
(\% 0,8)\end{array}$ & $P>0.05$ & $1,06 \pm 0,51$ \\
\hline \multicolumn{9}{|c|}{ Ot } \\
\hline Gövde & $0,26 \pm 0,07 \mathrm{a}$ & $0,13 \pm 0,07 \mathrm{a}$ & $0,06 \pm 0,01 \mathrm{a}$ & $0,14 \pm 0,06 \mathrm{a}$ & $0,07 \pm 0,01 \mathrm{a}$ & & $P>0,05$ & $0,13 \pm 0,03$ \\
\hline Kök & $0,72 \pm 0,17 \mathrm{a}$ & $0,45 \pm 0,25 \mathrm{a}$ & $0,30 \pm 0,03 \mathrm{a}$ & $0,59 \pm 0,14 \mathrm{a}$ & $0,44 \pm 0,21 \mathrm{a}$ & & $P>0,05$ & $0,49 \pm 0,07$ \\
\hline Toplam & $\begin{array}{c}0,98 \pm 0,21 \mathrm{a} \\
(\% 1,5)\end{array}$ & $\begin{array}{c}0,58 \pm 0,31 \mathrm{a} \\
(\% 1,0)\end{array}$ & $\begin{array}{c}0,36 \pm 0,03 \mathrm{a} \\
(\% 0,4)\end{array}$ & $\begin{array}{c}0,73 \pm 0,19 \mathrm{a} \\
(\% 0,7)\end{array}$ & $\begin{array}{c}0,51 \pm 0,22 \mathrm{a} \\
(\% 0,3)\end{array}$ & & $P>0,05$ & $0,63 \pm 0,09$ \\
\hline \multicolumn{9}{|c|}{ Ölü örtü } \\
\hline & - & $\begin{array}{c}3,65 \pm 1,100 \mathrm{a} \\
(\% 6,1)\end{array}$ & $\begin{array}{l}4,05 \pm 1,52 \mathrm{a} \\
(\% 4,6)\end{array}$ & $\begin{array}{c}6,80 \pm 1,40 \mathrm{ab} \\
(\% 6,9) \\
\text { Toprak }\end{array}$ & $\begin{array}{c}8,97 \pm 1,24 b \\
(\% 4,8)\end{array}$ & $\begin{array}{c}7,87 \pm 0,67 \mathrm{~b} \\
(\% 3,7)\end{array}$ & $P<0,05$ & $6,55 \pm 0,62$ \\
\hline & $\begin{array}{c}60,2 \pm 12,5 \mathrm{abc} \\
(\% 91,1)\end{array}$ & $\begin{array}{c}41,9 \pm 19,9 \mathrm{ab} \\
(\% 70,1)\end{array}$ & $\begin{array}{c}55,2 \pm 9,8 \mathrm{abc} \\
(\% 62,2)\end{array}$ & $\begin{array}{c}40,6 \pm 6,3 a \\
(\% 41,2)\end{array}$ & $\begin{array}{c}77,9 \pm 13,6 b c \\
(\% 41,6)\end{array}$ & $\begin{array}{c}81,3 \pm 6,3 \mathrm{c} \\
(\% 38,2)\end{array}$ & $P<0,05$ & $60,9 \pm 5,0$ \\
\hline \multicolumn{9}{|c|}{ Toplam } \\
\hline & $\begin{array}{c}66,1 \pm 13,2 \mathrm{a} \\
(100 \%) \\
\end{array}$ & $\begin{array}{c}59,8 \pm 18,8 \mathrm{a} \\
(100 \%) \\
\end{array}$ & $\begin{array}{c}88,8 \pm 11,4 \mathrm{ab} \\
(100 \%)\end{array}$ & $\begin{array}{c}98,6 \pm 9,7 \mathrm{ab} \\
(100 \%)\end{array}$ & $\begin{array}{c}187,3 \pm 15,9 b c \\
(100 \%) \\
\end{array}$ & $\begin{array}{c}213,0 \pm 17,2 \mathrm{c} \\
(100 \%)\end{array}$ & $P<0,001$ & $130,22 \pm 13,6$ \\
\hline
\end{tabular}

\section{Tartışma}

\subsection{Bitkisel kütle denklemleri ve katsayıları}

Ağaç bileşeni kütlelerinin tahmininde $d_{1,3}, h$ ve $\mathrm{d}_{1,3}{ }^{2} \mathrm{~h}$ indeksi kullanılmış olup ibre, canlı dal, toprak üstü ve toplam ağaç kütlesinde compound $\left(y=a b^{x}\right)$ modeli, kuru dal, gövde, kabuk ve kök kütlesinde power $\left(\mathrm{y}=\mathrm{ax}^{\mathrm{b}}\right)$ modeli en iyi tahmini sağlamıştır. Canlı dal, kabuklu gövde, kabuksuz gövde, kabuk, toprak üstü, kök ve toplam ağaç kütlesini $\mathrm{d}_{1,3}$; kuru dal kütlesini ise $\mathrm{d}_{1,3}{ }^{2} \mathrm{~h}$ indeksi en iyi tahmin etmiştir. Keza, konu ile ilgili yapılan çalışmalarda da benzer bulgular elde edilmiştir (Cienciala ve ark. 2006, Mikšys ve ark. 2007, Çömez 2012, Tolunay 2012). Fidan $(\mathrm{d} 1,3<8 \mathrm{~cm})$ bileşeni kütlelerinin tahmininde $\mathrm{d}_{0}, \mathrm{~h}$ ve $\mathrm{d}_{0}{ }^{2} \mathrm{~h}$ indeksinin kullanıldı ğ 1 denklemlerde kabuklu gövde kütlesini quadratic model, diğer fidan bileşenlerinin kütlesinde power ve $\mathrm{S}$ modeli en iyi tahmin etmiştir. Canlı dal, kabuklu gövde ve kabuk kütlesi $\mathrm{d}_{0}{ }^{2} \mathrm{~h}$ indeksini; ibre, kabuksuz gövde, toprak üstü, kök ve toplam fidan kütlesini ise $d_{0}$ en iyi tahmin etmiştir.
Araştırma kapsamında örneklenen ağaçların göğüs yüksekliğindeki çapları 1,5 - 41,4 cm arasında değişmektedir. Göğüs çap1 42 cm'den küçük ağaçlar için sedir türüne ait denklemlerin karşılaştırılması Şekil 2'de verilmiştir. Şekil 2 incelendiğinde Durkaya ve ark. (2013) tarafından göğüs yüksekliğindeki çapı 8-43 cm arasında değişen doğal sedir ormanları için geliştirilen denklemlerle, bu çalışmada elde edilen denklemler karşılaştırıldığında, toplam dal kütlesi, kabuklu gövde kütlesi ve toprak üstü ağaç kütlesi bakımından denklemler arasındaki farklılıklar önemsiz $(P>0,05)$, ibre kütlesi bak1mindan ise önemli bulunmuştur $(P<0,05)$. Güner ve Çömez (2017) tarafından yapılan çalışmada, karaçam türü için doğal ve plantasyon ormanlarına ait toprak üstü bitkisel kütle denklemleri karşılaştırılmış ve denklemler arasında farklılıkların olduğu belirlenmiştir. Ancak bu çalışmada, sedir türü için doğal ve plantasyon ormanlarına ait denklemlerin birbirlerine oldukça yakın bir seyir takip ettiği görülmüştür. $\mathrm{Bu}$ durumun büyük oranda türün biyolojik özelliğinden kaynaklandığı düşünülmektedir. 

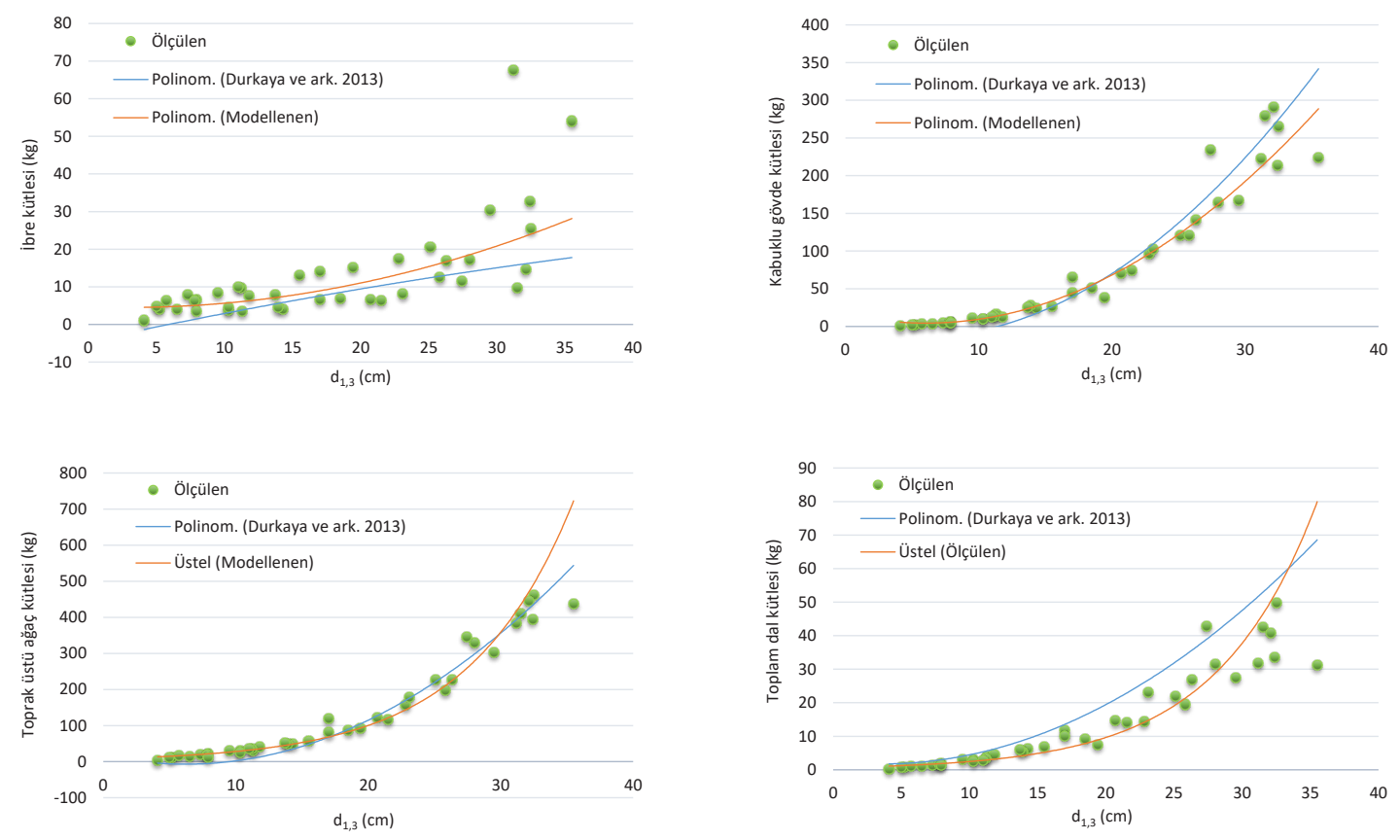

Şekil 2. Sedir için geliştirilen bazı toprak üstü bitkisel kütle denklemlerinin karşılaştırılması Figure 2. Comparison of aboveground biomass equations developed for Cedar

Bu çalışmada, hacim ağırlığı ortalama $0,467 \mathrm{t} / \mathrm{m}^{3}$ bulunmuş olup, meşcere tipleri arasında önemli bir farklılık göstermemiştir. Keza Ülküdür (2010) sedir gövde odunu hacim ağırlığını $0,430 \mathrm{t} / \mathrm{m}^{3}$ olarak belirlemiştir. Bu çalışmada, meşcere tiplerine göre değişmekle birlikte sedir ağaçlandırmaları için BGK $_{\text {TOPRAKÜSTÜ }}$ değeri 1,635 olarak bulunmuştur. Ülkemizde sera gazları ulusal envanterinde ibreli türler için toprak üstü bitkisel kütle genişletme katsayıs1 1,22 olarak alınmaktadır (NIR Turkey 2013). Ülküdür (2010)'a atfen Tolunay (2013) sedir için BGK $_{\text {торRAKÜstü }}$ değerini 1,300 olarak hesaplamıştır. Toprak üstü bitkisel kütle genişletme katsayısına ait bulgumuzun Tolunay (2013) tarafindan bildirilen ve ulusal bildirimlerde kullanılan katsayılardan daha yüksek olduğu görülmektedir. Bunun sebebi, yukarıda ifade edildiği gibi ağaçlandırmalarda birim alandaki fert sayısının doğal ormanlara göre daha az olması ve mevcut fertlerin başlangıçtan itibaren daha geniş bir tepe tacı geliştirmesidir.

BDGK $_{\text {KURUDAL }}$, BDGK $_{\text {KBSGÖVDE }}$, BDGK $_{\text {KABUK }}$ ve

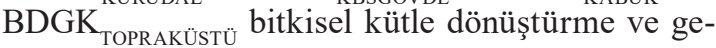
nişletme katsayıları meşcere tipleri arasında önemli bir farklılık göstermemiş olup, sırasıyla 0,0480,388-0,079 ve $0,762 \mathrm{t} / \mathrm{m}^{3}$ bulunmuştur. İbre, kök ve toplam bitkisel kütle dönüştürme ve genişletme katsayıları ise meşcere tipleri arasında önemli farklılık göstermiştir. BDGK ${ }_{\mathrm{KABUK}}$ katsayısının b meşcerelerinde daha yüksek bulunmasının sebebinin ağacın gelişimi ile birlikte kabuk oranının azalma- sından kaynaklandığ 1 düşünülmektedir. Güner ve Çömez (2017) tarafından karaçamda yapılan çalışmada da benzer bulgulara ulaşılmıştır. Sedir ağaç-

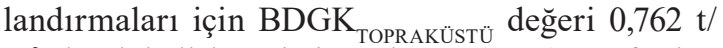
$\mathrm{m}^{3}$ olarak belirlenmiştir. Tolunay (2013) tarafından yapılan çalışmada ise sedir için BDGK değeri $0,559 \mathrm{t} / \mathrm{m}^{3}$ olarak hesaplamıştır. Toprak üstü bitkisel kütle dönüştürme ve genişletme katsay1sına ait bulgularımız, Tolunay (2013) tarafindan bildirilen katsayılardan daha yüksek düzeydedir. Bunun sebebi ise yukarıda ifade edildiği gibi plantasyonların başlangıçtan itibaren daha serbest büyümesi, dolayısıyla daha geniş bir tepe yapısına sahip olmasından kaynaklandığı düşünülmektedir.

Araştırmada kök/sak oranı meşcere tipleri arasında önemli bir farklılık göstermemiş olup, ortalama olarak 0,207 bulunmuştur. Kök/sak oranı karaçam ağaçlandırmalarında 0,179 (Güner ve Çömez 2017), Sitka ladininde 0,23 (Green ark. 2005), fistık çamında 0,30 (Correia ve ark. 2010), sarıçamda 0,209 (Çömez 2012), Pinus ponderosa Laws. ağaçlandırmalarında 0,21-0,25 arasında bulunmuștur (Laclau 2003). IPCC (2006), ibreli ağaç türleri için kök/sak oranlarını toprak üstü ağaç kütlesine göre ayrı ayrı verilmiştir. Buna göre, kök/sak oranının, ılıman kuşakta toprak üstü ağaç kütlesi $50 \mathrm{t} /$ ha'dan az olan ormanlarda 0,$40 ; 50-150 \mathrm{t} /$ ha olan ormanlarda 0,$29 ; 150 \mathrm{t} /$ ha'dan fazla olan ormanlarda ise 0,20 olarak alınabileceği bildirilmektedir. Bu çalışmada, toprak üstü ağaç kütlesi a, a3 ve b2 meşcerele- 
rinde $50 \mathrm{t} / \mathrm{ha}$ 'dan $\mathrm{az}, \mathrm{b}_{3}$ meşcerelerinde $50-150 \mathrm{t} / \mathrm{ha}$ arasında, c2 ve c3 meşcerelerinde ise $150 \mathrm{t} /$ ha'dan daha fazla bulunmuştur. Buna göre araştırmamıza konu sedir ağaçlandırma alanlarında kök/sak oranı diğer araştırma bulguları ile uyum içerisindedir. Ancak, a ve b meşcerelerine ait kök/sak oranları IPCC (2006)'de verilen değerden daha düşük düzeyde bulunmuştur. $\mathrm{Bu}$ durum, türün biyolojik yapısından ve yetişme ortamı özellikleri (toprak, iklim, vb.) arasındaki farklılıktan kaynaklanmış olabileceği düşünülmektedir.

Karbon oranlarının ağaç türlerine ve bileşenlerine göre önemli farklılıklar gösterdiği bildirilmektedir (Lamlom ve Savidge 2003, Tolunay 2009, Thomas ve Martin 2012). Bu çalışmada, ibre, canlı dal ve kök dışında ağaç bileşenlerinin karbon oranları meşcere tipleri arasında önemli farklılıklar göstermiştir. Genel olarak c meşcerelerindeki karbon oranları $\mathrm{a}$ ve $\mathrm{b}$ meşcerelerinden daha yüksek düzeyde bulunmuştur. Güner ve Çömez (2017) tarafından karaçam ağaçlandırmalarında yapılan çalışmada da benzer bulgulara ulaşılmıştır. Bozkurt (1986), ağaç yaşının artmasına bağlı olarak odunun lignin içeriğinin arttığını bildirmekle birlikte, Güler ve ark. (2007) genç karaçamlarda lignin içeriğini yaşlı karaçamlardan daha yüksek bulmuştur. Ancak söz konusu çalışmada, yaşlı karaçam odununda, karbon içeriği \%80’i bulabilen ekstraktif maddelerin daha fazla olduğu ortaya konmuştur. Çalışmamızda c meşcerelerindeki karbon oranlarının yüksek çıkması, karbon içeriği \%63-66 arasında değişen ligninin (Bert ve Danjon 2006) veya karbon içeriği \%80'lere ulaşan ekstraktif maddelerin (Güler ve ark. 2007) yaşlı ağaçlarda daha fazla olmasından kaynaklanabilir. Ayrıca ağaç bileşenlerinin karbon oranları arasında da istatistiksel bakımdan önemli farklılıklar bulunmuştur. En yüksek karbon oranı kabukta $(\% 51,74)$, en düşük karbon oranı ise kökte $(\% 49,34)$ tespit edilmiştir. Durkaya ve ark. (2013) Toros sedirinin karbon oranını kabuk için \%51,1 ibre için \%52,8 olarak bildirmektedir. Toros sediri doğal ormanlarında belirlenen bu değerlerden ibre karbon içeriği çalışmamızda belirlenenden bir miktar yüksektir. Ancak dal için belirlenmiş olan karbon içeriği $(\% 50,6)$ çalışmamızda belirlenen dal karbon içeriğinden $(\% 51,6)$ daha düşüktür. Bu durum yetişme ortamlarının farklılığ1 ya da ağaçlandırmanın ağaçların karbon içeriği üzerinde etkili olabileceğini göstermektedir. Yapılan araştırmalarda ağaç bileşenleri içinde kabuğun karbon oranının genel olarak diğer bileşenlerden daha fazla olduğu belirlenmiştir (Çömez 2012, Tolunay 2009, Güner ve Çömez 2017). İbreli ağaçlarda odunun lignin içeriği en çok \%30 civarında olurken kabukta bu oran \%55'e kadar yükselmektedir. Ayrıca kabuğun ekstraktif madde içeriği odundan yaklaşık 3 kat daha fazla olabilmektedir (Dönmez ve Dönmez 2013). Kabukta karbon oranının yüksek bulunması ligninin veya ekstraktif maddelerin fazlalığından kaynaklanmaktadır. Sedir ağaçlandırmalarında, ağaç kütlesi karbon oranı ağırlıklı olarak \%51,27 olarak bulunmuştur. Ağaç kütlesi karbon oranı, Sitka ladininde $\% 52 \pm 1$ (Green ve ark. 2005), sahil çamında \%53,2 (Bert ve Danjon 2006), sarıçamda \%52,46 (Çömez 2012), karaçam ağaçlandırmalarında \%53,86 (Güner ve Çömez 2017) olarak bulunmuştur. AKAKDO kılavuzunda karbon oranının $\% 50$ (IPCC 2003); AFOLU kılavuzunda ise 1lıman kuşak ibreli ormanları için \%51, yapraklı ormanlar için \%48 alınabileceği bildirilmektedir (IPCC 2006). Sedir ağaçlandırmaları için bulunan karbon oranı AFOLU klavuzu ile uyum içerisindedir.

Sedir ağaçlandırmalarında, birim alandaki ağaç bileşenleri karbon stoğu, meşcere tipleri arasında önemli farklılıklar göstermiştir. Toplam ağaç kütlesi karbon stoğu bakımından a $(4,885 \mathrm{t} / \mathrm{ha})$ ve a3 (13,672 t/ha) meşcereleri bir grup, b2 $(28,866$ t/ha) ve b3 (50,468 t/ha) meşcereleri bir grup, c2 (96,677 t/ha) ve c3 meşcereleri (122,031 t/ha) ise bir grup oluşturmuştur. c3 meşcerelerindeki toplam ağaç kütlesi karbon stoğunun yüksek çıkması, diğer meşcerelere göre daha fazla ağaç kütlesine sahip olmasından kaynaklanmıştır. Keza, karaçam ağaçlandırmalarında, ağaç kütlesi karbon stoğu bakımından a $(2,225 \mathrm{t} / \mathrm{ha})$ ve a3 $(10,976 \mathrm{t} / \mathrm{ha})$ meşcereleri bir grup, b2 $(55,628 \mathrm{t} /$ ha), b3 $(68,937 \mathrm{t} / \mathrm{ha})$ ve c2 $(82,091 \mathrm{t} / \mathrm{ha})$ meşcereleri bir grup, c3 meşcereleri $(119,686 \mathrm{t} / \mathrm{ha})$ ise bir grup oluşturmuştur (Güner ve Çömez 2017).

Araştırma kapsamında diri örtü çalı ve ot olmak üzere iki kısımda değerlendirilmiştir. Sedir ağaçlandırmalarında birim alandaki çalı kütlesi meşcere tipleri arasında önemli bir farklılık göstermemiş olup, ortalama 2,183 t/ha bulunmuştur. Benzer şekilde, karaçamda yapılan çalışmada da birim alandaki çalı kütlesi meşcere tipleri arasında önemli bir farklılık göstermemiştir (Güner ve Çömez 2017). Araştırma alanlarında çalı olarak alıç, kuşburnu ve ardıç türleri tespit edilmiştir. Bu üç türün karbon oranları arasında önemli düzeyde bir farklılık belirlenememiştir. Keza, çalı karbon stoğu bakımından da meşcere tipleri arasındaki farklılıklar önemsiz bulunmuştur. Birim alandaki ot kütlesi meşcere tipleri arasında önemli bir farklılık göstermemiştir. Ot bileşenlerinin karbon oranları ve ot karbon stoğu ot kütlesinde olduğu gibi meşcere tipleri arasında önemli bir farklılık göstermemiştir. Çünkü karbon stoğu kütle ile orantılı olarak azalmakta veya artış göstermektedir.

Ölü örtü karbon oranları meşcere tipleri arasında önemli farklılıklar göstermiştir. Ölü örtü karbon 
oranı Sa3 meşcerelerinde en yüksek $(\% 45,94), \mathrm{Sc} 3$ meşcerelerinde ise en düşük düzeyde $(\% 36,79)$ bulunmuştur. Ölü örtü karbon içeriği ortalama $\% 41,87$ dir. Bu çalışmada, ölü örtü tabakaları net bir şekilde ayırt edilemediği için ölü örtü örnekleri tek bir örnek şeklinde yapılmıştır. Ölü örtü karbon oranının a meşcerelerinden $\mathrm{c}$ meşcerelerine doğru düzenli bir şekilde azalmasının meşcere yaşının artması ile bir miktar ölü örtü ayrışmasından kaynaklandığ 1 düşünülmektedir. Özdemir ve ark. (2013), ölü örtü karbon oranlarını meşede $\% 48,5$, sahil çamında ise orjinlere bağlı olarak \%50,4 ile \%54,0 arasında bulmuştur. Sevgi ve ark. (2011) ise ölü örtü karbon içeriklerini saçlı meşede \%31,0, karaçam türü için \%34,9 olarak belirlemiştir. Sarıçamda karbon içeriği yaprak ve çürüntü tabakalarında \%50, humusta ise \%40 bulunmuştur (Tolunay 2009). Ölü örtü karbon içeriği ibreli ormanlarda yapraklı ormanlardan daha yüksek bulunmaktadır (Schulp ve ark. 2008). Ölü örtünün karbon içeriği ayrışma derecesi ve ölü örtü tabakalarının bulunuş miktarıyla ilgili olup, ölü örtü tabakalarının karbon içerikleri de farklıdır. Yetişme ortamı koşulları ölü örtü tabakalarının bulunuş miktarlarını da etkilemektedir. Sedir ağaçlandırma alanlarında ölü örtü kütlesi ve ölü örtü karbon stoğu meşcere tipleri arasında önemli farklılıklar göstermiş, ölü örtü kütlesi ve karbon stoğu a3 mesçerelerinde (3,647 t C/ha) en az, c3 mesçerelerinde $(8,969 \mathrm{t} \mathrm{C} / \mathrm{ha})$ ise en fazla bulunmuştur. Güner ve Çömez (2017), karaçam ağaçlandırma alanlarında ölü örtü karbon stoğun benzer şekilde a3 mesçerelerine (1,96 t C/ha) en az, c mesçerelerinde ise $(12,49 \mathrm{t} \mathrm{C} / \mathrm{ha})$ en fazla bulmuştur. Ayrıca ülkemizdeki sedir ağaçlandırma alanlarında ölü örtü karbon stoğu 1,7 ile 19,0 t/ha bulunmuştur (Tolunay ve Çömez 2008). Ölü örtü karbon stoğuna ait bulgularımız sedir ağaçlandırma alanlarında yapılan çalışmalarla uyum içerisindedir.

\subsection{Toprak}

Araştırma alanlarında iki toprak tipi belirlenmiştir. Bunlardan esmer orman topraklarındaki Ah, Bv, $\mathrm{BC}, \mathrm{Cv}$ horizonlarına ait ortalama organik karbon değerleri sırasıyla $\% 2,52, \% 1,29, \% 0,66$ ve $\% 0,43$; solgun esmer orman topraklarındaki Ah, Ael, Bst, $\mathrm{BC}, \mathrm{Cv}$ horizonlarına ait ortalama organik karbon değerleri sırasıly $\% 6,36, \% 1,98, \% 0,99, \% 0,48$ ve $\% 0,69$ bulunmuştur. Toprağın karbon içeriği üst horizonlardan alt horizonlara doğru azalma göstermiştir. Toprakların karbon stokları meşcere tipleri arasında önemli farklılıklar göstermiştir. Toprak karbon stoğu Sb3 meşcerelerinde (40,599 t/ha) en az, Sc3 meşcerelerinde (81,316 t/ha) en fazla bulunmuştur. Sedir ağaçlandırma alanlarında ortalama toprak karbon stoğu 60,875 t/ha olarak belirlenmiştir. Topraktaki organik karbon stoğu doğal ibreli ormanlarda $85,7 \mathrm{t}$ /ha $(12,6-273,1)$, ağaçlandirma alanlarında 74,6 t/ha $(38,7-92,7)$, ibreli karış1k (sedir-karaçam) ormanlarda 50,8 $(18,5-82,1)$ arasında bulunmuştur (Tolunay ve Çömez 2008). Toprak karbon stoğuna ilişkin bulgularımız, Tolunay ve Çömez (2008)'in bildirdiğinden daha düşük düzeyde bulunmuştur. Yukarıda görüldüğü gibi, toprak karbon stoğu araştırmalar arasında hatta aynı araştırma içerisinde bile geniş bir varyasyon göstermektedir. $\mathrm{Bu}$ durumun, araştırma alanlarındaki toprakların sahip olduğu ince toprak miktarı ve karbon oranları arasındaki farklılıktan kaynaklandığı düşünülmektedir. Toprağın karbon oranları üzerinde organik madde girişi ve organik maddenin ayrışması hızı (Tolunay ve Çömez 2007) ile toprak içerisindeki ince kök ayrışmasının (Berg ve McClaugherty 2003) etkili olduğu bildirilmektedir.

\subsection{Ekosistemdeki Karbon Stokları}

Sedir ağaçlandırma alanlarındaki toplam karbon stoğu meşcere tiplerine göre önemli farklılıklar göstermiştir. Toplam karbon stoğu Sa3 meşcerelerinde en az (59,8 t/ha), Sc3 meşcerelerinde en fazla bulunmuştur (213,0 t/ha). Ekosistemdeki karbon stoklarının toplam karbon stoğuna oranı meşcere tiplerine göre farkl1lıklar göstermektedir. Sa meşcerelerinde ağaç kütlesi karbon stoğu, toplam karbon stoğunun \%7,4'ünü oluştururken bu oran Sc3 meşcerelerinde \%57,3'e kadar çıkmaktadır. Toprak karbon stoğunun toplam karbon stoğuna oranı, Sa meşcerelerinde \%91,1 iken bu oran Sc3 meşcerelerinde \%38,2'ya kadar azalmaktadır. Diri örtü karbon stoklarının toplam karbon stoklarına katılma oranı oldukça düşük düzeydedir. Ölü örtü karbon stoğunun toplam karbon stoğuna katılma oranı $\% 3,7$ ile \%6,9 arasında gerçekleşmiştir. Ortalama değerlere göre, sedir ağaçlandırma alanlarında toplam karbon stoğu 130,22 t/ha olarak bulunmuştur.

\section{Sonuçlar ve Öneriler}

Sedir ağaçlandırma alanlarında, ekosistemin farklı bileşenlerinde depolanan karbon stoklarını belirlemek amacıyla gerçekleştirilen bu çalışmada aşağıdaki sonuçlara ulaşılmıştır:

(1) Tek ağaç (Bkz. Tablo 3) kütlesinin tahmininde bu çalışmada belirlenen denklemler kullanılabilir.

(2) Amenajman verilerinden yararlanılarak sedir ağaçlandırma alanlarında meşcere kütlesini hesaplamak için belirlenen katsayılar Tablo 4'de verilmiştir. Buna göre hacim ağırlığ 1 $0,467 \mathrm{t} / \mathrm{m}^{3}, \quad$ BGK BDGK $_{\text {TOPRAKÜSTÜ }} 0,762 \mathrm{t} / \mathrm{m}^{3}, \mathrm{kök} / \mathrm{sak}$ oranı 


\section{0,207 olarak kullanılabilir.}

(3) Ağaç bileşenlerinin karbon içerikleri ibrede $\% 51,11$; kuru dalda $\% 50,99$; canlı dalda $\% 51,60$; kabuksuz gövdede $\% 51,71$; kabukta $\% 51,74$; kabuklu gövdede $\% 51,74$; toprak üstü ağaç kütlesinde \%51,65; kökte \%49,34 ve toplam ağaç kütlesinde ise $\% 51,27$ bulunmuştur. Bu karbon oranları, sedir meşcerelerinde ağaçların çeşitli bileşenlerinde depolanan karbon miktarlarının hesaplanmasında kullanılabilir. Gerek katsayılarla gerekse denklemlerle hesaplanan ağaç kütlesi, $\% 51,27$ 'lık karbon içeriği ile çarpılmak suretiyle ağaçlardaki karbon stoğu bulunabilir.

(4) Sedir ağaçlandırma alanlarında ortalama çalı kütlesi 2,183 t/ha, ot kütlesi 1,888 t/ha; karbon içeriği çalı için $\% 48,86$ ve ot için $\% 33,43$ bulunmuş olup elde edilen kütle ve karbon oranları hesaplamalarda kullanılabilir.

(5) Ölü örtü kütlesi meşcere tiplerine göre önemli farklar göstermiştir. Ölü örtünün kütlesi Sa3, $\mathrm{Sb} 2, \mathrm{Sb} 3, \mathrm{Sc} 2$ ve $\mathrm{Sc} 3$ meşcerelerinde sırasıyla 3,$65 ; 4,05 ; 6,80 ; 8,97$ ve 7,87 t/ha, karbon içeriği ortalama $\% 41,87$ bulunmuş olup elde edilen kütle ve karbon oranları hesaplamalarda kullanılabilir.

(6) $\mathrm{Bu}$ çalışmada, toprak karbon stoğu meşcere tipleri arasında önemli bir farklılık göstermiştir. Toprak karbon stoğu üzerinde meşcere özellikleri, toprak özellikleri, ölü örtü ayrışma hızı, iklim özellikleri gibi çok sayıda faktör etkili olduğu için, daha kapsamlı modelleme çalışmalarına ihtiyaç vardır. Daha ayrıntılı çalışmalar yapılana kadar sedir ağaçlandırmaları için toprak karbon stoğu ortalama 60,875 t/ha alınabilir.

(7) Sedir ağaçlandırma alanlarındaki toplam karbon stoğu meşcere tipleri arasında önemli farklar göstermiştir. Toplam karbon stoğu Sa3, $\mathrm{Sb} 2, \mathrm{Sb} 3, \mathrm{Sc} 2$ ve Sc3 meşcerelerinde sırasıyla 59,$84 ; 88,78 ; 98,60 ; 187,27$ ve 213,00 t/ha bulunmuştur. Sedir ağaçlandırmaları için toplam karbon stoğu ortalama 130,22 t/ha alınabilir.

\section{Teşekkür}

"Eskişehir Orman Bölge Müdürlüğü Sedir (Cedrus libani A. Rich.) Ağaçlandırma Alanlarında Karbon Stoklarının Belirlenmesi (ESK-13(6310)/20122016)" isimli bu araştırma Orman Genel Müdürlüğü tarafından desteklenmiştir. Arazi çalışmalarımızda gerekli desteği sağlayan Eskişehir Orman Bölge Müdürlüğü çalışanlarına teşekkür ederiz.

\section{Kaynaklar}

Akgül, E., Y1lmaz, A., 1986. Doğal Yayılış Alanları Dışında Yapılan Ağaçlandırmalarda Yörenin Ekolojik Özellikleri İle Toros Sedirinin (Cedrus libani A. Rich) Gelişimi Arasındaki İlişkiler, Ormancılık Araştırma Enstitüsü Müdürlüğü, Teknik Bülten Serisi No. 188, 50 s.

Berg, B., Mcclaugherty, C., 2003. Plant litter decomposition, humus formation, carbon sequestration, SpringerVerlag Berlin Heiderberg, Germany, 3-540-44329-0.

Bert, D., Danjon, F., 2006. Carbon concentration variations in the roots, stem and crown of mature Pinus pinaster (Ait.). Forest Ecology and Management 222, 279-295.

Bozkurt, Y., 1986. Ağaç Teknolojisi, İ.Ü.O.F. Yayınları, İ.Ü.Yayın No: 3403, O.F.Yayın No: 380, İstanbul, 220 s.

Cienciala, E., Černý, M., Tatarinov, F., Apltauer, J., Exnerová, Z., 2006. Biomass functions applicable to Scots pine, Trees 20, 483-495.

Correia, A.C., Tomé, M., Pacheco, C.A., Faias, S., Dias, A.C., Freire, J., Carvalho, P.O., Pereira, J.S., 2010. Biomass allometry and carbon factors for a Mediterranean pine (Pinus pinea L.) in Portugal, Forest Systems 19 (3), 418-433.

Çepel, N., Dündar, M., Günel, A., 1977. Türkiye'nin önemli yetişme bölgelerinde saf sarıçam ormanlarının gelişimi ile bazı edafik ve fizyografik etmenler arasındaki ilişkiler, TÜBİTAK, Tarım ve Ormancılık Araştırma Grubu, Proje No: TOAG 154, Tübitak Yayınları No: 354, TOAG Seri No: 65, Ankara, 165 s.

Çömez, A., 2012. Sündiken Dağları'ndaki (Eskişehir) Sarıçam (Pinus sylvestris L.) Meşcerelerinde Karbon Birikiminin Belirlenmesi, Orman ve Su İşleri Bakanlığ1, Orman Genel Müdürlüğü, Orman Toprak ve Ekoloji Araştırmaları Enstitüsü Müdürlüğü, Teknik Bülten No: 2, Eskişehir, $123 \mathrm{~s}$.

Dönmez, İ.E., Dönmez, Ș., 2013. A ğaç kabuğunun yapıs1 ve yararlanma imkanlar1. SDÜ Orman Fakültesi Dergisi $14,156-162$.

Durkaya, B., Durkaya, A., Makineci, E., Ülküdür, M., 2013. Estimation of above-ground biomass and sequestered carbon of Taurus Cedar (Cedrus libani L.) in Antalya, Turkey. iForest 6, 278-284.

Green, C., Tobin, B., O'Shea, M., Farrell, E.P., Byrne, K.A., 2005. Above- and belowground biomass measurements in an unthinned stand of Sitka spruce (Picea sitchensis (Bong) Carr.), Eur J Forest Res 126(2), 179-188.

Guler, C., Copur, Y., Akgul, M., Buyuksari, U., 2007. Some chemical, physical and mechanical properties of juvenile wood black pine (Pinus nigra Arnold) plantations, Journal of Applied Sciences 7(5), 755-758.

Gülçur, F., 1974. Toprağın Fiziksel ve Kimyasal Analiz Metodlar1, İÜ Orman Fakültesi Yayın Nu: 201, Kutulmuş Matbaası, İstanbul, $225 \mathrm{~s}$. 
Güner, Ş.T., Çömez, A., Karataş, R., Çelik, N., Özkan, K., 2011. Eskişehir ve Afyonkarahisar illerindeki Anadolu karaçamı (Pinus nigra Arnold. subsp. pallasina (Lamb.) Holmboe) ağaçlandırmalarının gelişimi ile bazı yetişme ortamı özellikleri arasındaki ilişkileri. Çevre ve Orman Bakanlığı, Orman Toprak ve Ekoloji Araştırmaları Enstitüsü Müdürlüğü, Teknik Bülten No: 1, Bakanlık Yayın No: 434, Eskişehir, 83 s.

Güner, Ș.T., Çömez, A., 2017. Biomass equations and changes in carbon stock in afforested black pine (Pinus nigra Arnold. subsp. pallasiana (Lamb.) Holmboe) stands in Turkey, Fresenius Environmental Bulletin, 26(3), 2368-2379.

IPCC, 2003. Good practice guidance for land use, landuse change and forestry, In: IGES, Eds. J. Penman, M. Gytarsky, T. Hiraishi, T. Krug, D. Kruger, R. Pipatti, L. Buendia, K. Miwa, T. Ngara, K. Tanabe, F. Wagner, IPCC/OECD/IEA/IGES, Hayama, Japan, http://www. ipcc-ggip.iges.or.jp/public/gpglulucf/gpglulucf_contents.html

IPCC, 2006. IPCC Guidelines for national greenhouse gas inventories, prepared by the National Greenhouse Gas Inventories Programme, In: IGES, Japan (Eds.: H.S. Eggleston, L. Buendia, K. Miwa, T. Ngara and K. Tanabe), http://www.ipcc-nggip.iges.or.jp/public/2006gl/ index.html.

Kalıpsız, A.K., 1994. İstatistik Yöntemler, İstanbul Üniversitesi Yayın No: 3835, Fakülte Yayın No: 427, İstanbul, $558 \mathrm{~s}$.

Kantarc1, M.D., 2000. Toprak İlmi, İ.Ü, Orman Fakültesi Yayınları, İ. Ü. Yayın No: 4261, O.F. Yayın No: 462, İstanbul, $420 \mathrm{~s}$.

Kantarc1, M.D., 2005. Orman Ekosistemleri Bilgisi, İstanbul Üniversitesi Orman Fakültesi Yayınları, İ.Ü. Yayın Nu: 4594, O.F. Yayın Nu: 488, İstanbul, 379 s.

Karataş, R., Özkan, K., 2017. Toros sediri (Cedrus libani A. Rich.) ağaçlandırmalarının gelişimi ile yetişme ortamı özellikleri arasındaki ilişkiler, Ormancılık Araştırma Dergisi, Seri: A, 4:1, 12-21.

Laclau, P., 2003. Biomass and carbon sequestration of ponderosa pine plantations and native cypress forests in northwest Patagonia. Forest Ecology and Management 180, 317-333.

Lamlom, S.H., Savidge, R.A., 2003. A reassessment of carbon content in wood: variation within and between 41 North American species, Biomass and Bioenergy 25, 381-388.

Mikšys, V., Varnagiryte-Kabasinskiene, I., Stupak, I., Armolaitis, K., Kukkola, M., Wójcik, J., 2007. Aboveground biomass functions for Scots pine in Lithuania, Biomass \& Energy 31, 685-692.

NIR Turkey, 2013. TURKEY Greenhouse Gas Inventory, 1990 to 2011, National Inventory Report Land Use, Land Use Change and Forestry, General Directorate of
Forestry, Ankara, 42s. https://unfccc.int/national reports/annex_i_ghg_inventories/national_inventories submissions/items/7383.php 24.09.2014

Nowak, D.J., Crane, D.E., 2002. Carbon storage and sequestration by urban trees in the USA, Environmental Pollution, 116, 381-389.

Özdamar, K., 2002. Paket Programlar ile İstatistiksel Veri Analizi-1, 4. Baskı, Kaan Kitabevi, Eskişehir, 686 s.

Özkan, K., 2000. Prof. Dr. Bekir Sitk1 EVCIMEN Sedir (Cedrus libani A. Rich) Koruma Ormanı'nda yükselti-iklim kuşaklarına göre toprak özelliklerinin analitik olarak incelenmesi, S.D.Ü. Orman Fakültesi Dergisi, Seri: A, Say1: 1, 21-40.

Özyuvacı, N., 1999. Meteoroloji ve Klimatoloji, İ.Ü, Orman Fakültesi Yayınları No: 4196, Dilek Ofset Matbaacılık, İstanbul, $369 \mathrm{~s}$.

Pamir, H.N., Erentöz, C. 1975. 1/500 000 Ölçekli Türkiye Jeoloji Haritası, Ankara Paftası, Maden Tetkik ve Arama Enstitüsü Yayınları, 111s, Ankara.

Polat, S., Polat, O., Kantarc1, M.D., Tüfekci, S., Aksay, Y., 2014. Mersin-Kadıncık Havzası'ndaki sedir (Cedrus libani A. Rich.) ve karaçam (Pinus nigra Arnold.) ağaçlandırmalarının boy gelişimi ile bazı yetişme ortamı özellikleri arasındaki ilişkiler, Ormancılık Araştırma Dergisi, 2014/1, A, 1:1, 22-37.

Ranger, J., Gelhaye, D., 2001. Bellowground biomass and nutrient content in a 47-year-old Douglas-fir plantation, Ann. For. Sci. 58-423-430.

Schulp, CJE., Nabuurs, GJ., Verburg, PH., Waal, RW., 2008. Effects of tree species on carbon stocks in forest flor and mineral soil and implications for soil carbon inventories. Forest Ecology and Management 256, 482-490.

Schimel, D., Enting, I.G., Heımann, M., Wigley, T.M.L., Raynaud, D., Alves, D., Siegenthaler, U., 2000. $\mathrm{CO}_{2}$ and the carbon cycle, In: The Carbon Cycle, Ed: Wigley, T.M.L., Schimel, D.S., Cambridge University Press, USA, 0-521-58337-3, 1-37.

Sevgi, O., Makineci, E., Karaöz, Ö., 2011. The forest floor and mineral soil carbon pools of six different forest tree species, Ekoloji 20(81), 8-14.

Sürücü, Z., 2012. Göller Bölgesi’ndeki Bazı Toros Sediri (Cedrus libani A. Rich.) Ağaçlandırmalarında Yetişme Ortamı Farklılığının Meşcere Gelişimine Etkisi, S.D.Ü., Fen Bilimleri Enstitüsü, Orman Mühendisliği Anabilim Dalı, Yüksek Lisans Tezi, 149 s., Isparta.

Thomas, S.C., Martin, A.R. 2012. Carbon content of tree tissues: A Synthesis, Forests 3, 332-352.

Tolunay, D., Çömez, A, 2007. Orman topraklarında karbon depolanması ve Türkiye'deki durum, Küresel İklim Değișimi ve Su Sorunlarının Çözümünde Ormanlar Sempozyumu, 13-14 Aralık 2007, İstanbul, 97-107.

Tolunay, D., Çömez, A, 2008. Türkiye topraklarında 
toprak ve ölü örtüde depolanmış organik karbon miktarları, Hava Kirliliği ve Kontrolü Ulusal Sempozyumu, 22-25 Ekim 2008, Hatay.

Tolunay, D., 2009. Carbon concentrations of tree components, forest floor and understorey in young Pinus sylvestris stands in North-western Turkey, Scandinavian Journal of Forest Research, 24: 394-402.

Tolunay, D., 2012. Bolu Aladağ'daki genç sarıçam meşcereleri için oluşturulan bitkisel kütle denklemleri ve katsayıları, İstanbul Üniversitesi Orman Fakültesi
Dergisi 62(2), 99-113

Tolunay, D., 2013. Türkiye'de ağaç servetinden bitkisel kütle ve karbon miktarlarının hesaplanmasında kullanılabilecek katsayılar. Ormancılıkta Sektörel Planlamanın 50. Y11ı Uluslararası Sempozyumu, 26-28 Kasim 2013, Antalya.

Ülküdür, M., 2010. Antalya Orman Bölge Müdürlüğü Sedir Meşcerelerinin Biyokütle Tablolarının Düzenlenmesi, Yüksek Lisans Tezi, Bartın Üniversitesi, Fen Bilimleri Enstitüsü, Bartın, 164 s. 